\title{
Importing Technology
}

Francesco Caselli and Daniel Wilson ${ }^{1}$

First Draft: October 2002; This Draft: March 2003

${ }^{1}$ Harvard University, CEPR, and NBER; and Federal Reserve Bank of San Francisco, respectively. Robert Feenstra, Chad Jones, Silvana Tenreyro, and seminar participants at the November 2002 FRBSF-SIEPR Conference on Technological Change provided helpful comments. Tariq Yasin and Geoffrey MacDonald provided excellent research assistance. Email addresses: caselli@harvard.edu, and Daniel.Wilson@sf.frb.org. This paper has been prepared for the Carnegie-Rochester Conference on Public Policy. 


\begin{abstract}
We look at disaggregated imports of various types of equipment to make inferences on crosscountry differences in the composition of equipment investment. We make three contributions. First, we document large differences in investment composition. Second, we explain these differences as being based on each equipment type's intrinsic efficiency, as well as on its degree of complementarity with other factors whose abundance differ across countries. Third, we examine the implications of investment composition for development accounting, i.e., for explaining the cross-country variation in income per capita.
\end{abstract}




\section{Introduction}

$Y=F(K, L)$ is equation (1) in virtually all papers that attempt to explain income differences across countries (development accounting). This is appropriate: differences in capital and labor explain a large fraction of the dispersion in income. It has also long been recognized that factor " $L$ " can usefully be disaggregated in order to enhance the explanatory power of $F$ for $Y$. Hence, distinctions between "raw labor" and "human capital"; or between "skilled labor" and "unskilled labor," have been successfully introduced in attempts to understand differences in income. In this paper, we propose to begin exploring an analogous disaggregation of factor " $K$ ". Specifically, we break down overall capital in nine equipment categories (from computers to motor vehicles). ${ }^{1}$

Direct measurements of the quantity of equipment installed in a country by type is, of course, not available. However, recent research by Eaton and Kortum (2001) has shown that most of the world's capital is produced in a small number of R\&D-intensive countries, while the rest of the world generally imports its equipment. This suggests that, for most countries, imports of capital of a certain type are an adequate proxy for overall investment in that type of equipment. This stylized fact motivates our empirical approach and, for the most part, this is a maintained assumption throughout our paper.

We make three contributions. First, we show that there is enormous cross-country variance in the composition of $K$ : different types of equipment constitute widely varying fractions of the overall capital stock across countries. Second, we shed a good deal of light on the determinants of these differences in composition. In particular, we estimate a simple model of investment in heterogenous types of capital, where a capital-type share in total investment depends on its intrinsic efficiency (reflecting embodied technology), as well as on the degree to which it is complementary with other inputs. For example, computers may be more complementary with human capital than other types of capital, leading to the prediction that human-capital abundant countries will devote a larger share of their investment to computers.

Our results indicate that, indeed, the intrinsic efficiency of equipment differs across equipment types: holding the supply of complementary factors constant, a dollar spent on one type of capital delivers more efficiency units than a dollar spent on another. Furthermore, we uncover clear patterns of differential complementarity between equipment types and other country characteristics (including, among many others, the human-capital-computers complementarity conjectured above): cross-country differences in human capital, institutions,

\footnotetext{
${ }^{1}$ For examples of development-accounting exercises see, among several others, Mankiw, Romer, and Weil (1992), Klenow and Rodriguez (1997), Hall and Jones (1999), Hendricks (2002), and Caselli and Coleman (2002).
} 
composition of GDP, financial development, and other factors have considerable explanatory power for differences in the composition of $K$. In addition, both the intrinsic efficiency, and the patterns of complementarity of different equipment types, can be rationalized with data on the R\&D intensity of the industries that produce them: equipment types coming out of high $\mathrm{R} \& \mathrm{D}$ industries are generally more complementary with factors that one would expect to be more relevant for the adoption of new technology.

Our third contribution is to begin examining the implications of differences in the composition of $K$ for cross-country income differences. Based on our simple model, we argue that $K$ as conventionally measured may fail to fully reflect quality differences. Since our empirical results show considerable variation in capital composition, as well as capital-type and country-specific differences in quality, this casts doubt on the validity of conclusions from the "standard" development-accounting exercise. We then perform a tentative variant of the development-accounting exercise where different types of capital contribute differently to output in different countries, and find that variation in capital quality can account for a significant fraction of the observed variation in GDP (quality matters!).

Besides contributing to the development-accounting research agenda, this paper is at the cross-roads of several other literatures. Since it tells a story where most countries acquire embodied technologies through capital imports from the world technological leaders, it directly adds to a series of contributions on cross-country technology diffusion. ${ }^{2}$ In this line of research, the paper is especially closely related to Caselli and Coleman (2001), who study the determinants of computer diffusion across countries. As in that paper, the main idea here is to look at equipment imports as measures of technology adoption by "follower" countries. This paper, however, generalizes the analysis to a larger number of equipment types - adding up to the total stock of equipment. Furthermore, in this paper we ground the empirical work into a theoretical model of investment in heterogeneous equipment types, and this allows us to more neatly map some of the empirical results into parameters describing the intrinsic efficiency of various types of capital, and to relate these parameters to the R\&D intensity of the industries where that capital is produced. ${ }^{3}$

We also add on previous evidence on the role of $R \& D$ in enhancing the efficiency units embodied in capital. Wilson (2002), for example, uses US data to compute measures of R\&D embodied in different types of capital. He then constructs an industry-level index of the $R \& D$ content of the overall capital stock employed by different industries, and shows that

\footnotetext{
${ }^{2}$ E.g. Grossman and Helpman (1991), Barro and Sala-i-Martin (1995), and Aghion and Howitt (1998) on the theory side, and Coe and Helpman (1995), Coe, Helpman and Hoffmeister (1997), Keller (1998), Eaton and Kortum (1999), Xu and Wang (1999), and Caselli and Coleman (2001), on the empirical side - see Keller (2001) for additional references and a survey of this literature.

${ }^{3}$ Our results on computers are consistent with the results in Caselli and Coleman (2001).
} 
an industry's TFP is increasing in this measure of the technology embodied in the capital it uses. Part of our paper builds on this approach: essentially, we look at a country's (as opposed to an industry's) capital composition by R\&D content, and relate this composition to the country's overall productivity.

The paper is also clearly related to the tradition on embodied technical change, which emphasizes differences in the efficiency units delivered by different vintages of capital. ${ }^{4}$ Particularly close here are those papers that, a la Jovanovic and Rob (1997), attempt to improve the success of the development-accounting exercise through vintage effects. Effectively, this is equivalent to breaking down $K$ by vintage, while maintaining the assumption that within a vintage capital is homogeneous. The difference here, of course, is that we do not break down $K$ by vintage but by type, i.e. we relax the within-vintage homogeneity assumption. While this has not been previously done in the development-accounting literature, this is best practice in the growth accounting literature. ${ }^{5}$

We emphasize differences in the patterns of complementarity between different types of equipment and various other factors that differ by country. Since we think of different types of equipment as embodying different technologies, this also implies that we provide direct evidence in support of theories of appropriate technology. ${ }^{6}$ In these theories, countries with different factor endowments optimally choose different technologies. In our setting this shows up in the composition of the capital stock by equipment type. Finally, we indirectly contribute to the literature on the composition of international trade flows. ${ }^{7}$

We start the rest of the paper with a simple model of investment in heterogeneous types of capital (Section 2). This model delivers predictions on the share of each type of capital in total investment, and in Section 3 we show how these predictions can be turned into an empirical model. Section 4 describes the data, and Section 5 presents empirical results on the composition of a country's investment. Our model also generates predictions on the relationship between the composition of investment and per-capita income: Section 6 investigates this relationship and assesses the role of quality in delivering the high explanatory power of real capital in development-accounting exercises. Section 7 summarizes the results.

\footnotetext{
${ }^{4}$ Solow (1960), Greenwood, Hercowitz, and Krusell (1997), and Jovanovic and Rob (1997), inter many alia.

${ }^{5}$ E.g. Jorgenson, Gollop, and Fraumeni (1987), and Young (1995).

${ }^{6}$ Examples: Atkinson and Stiglitz (1969), Diwan and Rodrick (1991), Basu and Weil (1998), Acemoglu and Zilibotti (2001), and Caselli and Coleman (2002).

${ }^{7}$ For a while the title of this paper was "The R\&D Content of Ttrade." See Hummels and Klenow (2002) for a recent decomposition of trade flows and further references to the literature.
} 


\section{Theory}

Imagine that in country $i$ final output $Y^{i}$ is produced combining various intermediate inputs, $x_{p}^{i}$, according to the CES production function ${ }^{8}$

$$
Y^{i}=B^{i}\left[\sum_{p=1}^{P}\left(x_{p}^{i}\right)^{\gamma}\right]^{\frac{1}{\gamma}} \quad \gamma<1,
$$

where $B$ is a disembodied total factor productivity term. Intermediate-good $p$ is produced combining equipment and labor:

$$
x_{p}^{i}=A_{p}^{i}\left(L_{p}^{i}\right)^{1-\alpha}\left(K_{p}^{i}\right)^{\alpha} \quad 0<\alpha<1,
$$

where $K_{p}^{i}\left(L_{p}^{i}\right)$ measures the quantity of equipment (labor) used to produce intermediateinput $p$, and $A_{p}^{i}$ is the productivity of sector $p$.

Our key assumption is that capital is heterogeneous: there are $P$ distinct types of capital, and each type is product specific, in the sense that intermediate $p$ can only be produced with capital of type $p$. In other words, an intermediate in our model is identified by the type of equipment that is used in its production. For example, for equipment-type "trucks," the corresponding intermediate good $x$ (say, "road transportation") is the one obtained by combining workers with trucks. For equipment-type "computers," the corresponding intermediate good is "computing services," etc. Hence, our intermediates do not easily map into industries or sectors (computers are used in most industries), but rather into the various types of activities (transport, computing, etc.) required to generate output within each sector. The assumption that $\gamma<1$ implies that - in producing aggregate output - all these activities are imperfect substitutes.

In contrast, for simplicity and in order to focus on the novel contribution of the paper, we assume here that labor is homogeneous within a country, though its quality can vary across countries, as we detail below. In the empirical work we will explore relaxations of this assumption. The $x$ production function allows for capital-labor substitutability. This feature is not very important but it facilitates linking up our model with the developmentaccounting literature.

The productivity term $A_{p}^{i}$ is both country, $i$, and product, $p$, specific. The idea behind country variation is that equipment of type $p$ may be more complementary with the endowments of country $i$. In this sense, different types of capital may be more or less appropriate for different countries. To understand product variation in $A$ it is essential first to clarify that - due to the nature of our data $-K_{p}^{i}$ is measured in US dollars, i.e. it is the

\footnotetext{
${ }^{8}$ Production functions such as this one have been the staple of recent developments in growth theory.
} 
US-dollar value of the capital stock of type $p$. Product variation in $A$ allows for the possibility that one dollar spent on equipment of type $p$ may deliver different amounts of efficiency units if instead spent on type $p^{\prime}$. For example, the embodied-technology content of good $p$ may be greater, say because the industry producing equipment of type $p$ is more $\mathrm{R} \& \mathrm{D}$ intensive. Our empirical work will allow us to learn about how $A_{p}^{i}$ varies systematically with $i$ and with $p$, and what this implies for furthering our understanding of cross-country differences in $Y_{.}^{9,10}$ Since the $K_{p}^{i}$ s are measured in dollars, we can write:

$$
\sum_{p} K_{p}^{i}=K^{i}
$$

where $K^{i}$ is the total amount of dollars devoted to investment, which we take as given. ${ }^{11}$ We assume that labor is fully mobile across types of capital, and denote by $L^{i}=\sum_{p} L_{p}^{i}$ the aggregate labor supply. Note that in equilibrium this economy will feature aggregate constant returns to scale in $K^{i}$ and $L^{i}$ (see below).

Since labor is perfectly mobile across the production processes $p$, producers in all sectors face a horizontal labor supply schedule with wage $w^{i}$. Furthermore, if investors allocate their dollars so as to arbitrage away differences in the rental rate of capital, producers face a common user cost $r^{i}$. Define $\xi_{p}^{i}=K_{p}^{i} / K^{i}$ the share of capital-type $p$ in the aggregate capital stock. Under our assumptions, in equilibrium we have

$$
\xi_{p}^{i}=\frac{\left(A_{p}^{i}\right)^{\frac{\gamma}{1-\gamma}}}{\sum_{j}\left(A_{j}^{i}\right)^{\frac{\gamma}{1-\gamma}}} .
$$

This expression (derived in the appendix) simply states that investment tends to concentrate on the equipment types that feature the highest embodied efficiencies, but this is counterbalanced to some extent by the diminishing returns to each intermediate input produced with those equipment types (because $\gamma<1$ ).

This result should also clarify why in equilibrium different equipment types can deliver different amounts of efficiency units per dollar. If $\gamma=1$ (perfect substitutability among

\footnotetext{
${ }^{9}$ In order to make sure that cross-country differences in $K_{p}^{i}$ measures physical differences in installed capital we need to assume that the law of one price holds. This is plausible, since we know that most capital is imported from a few world producers.

${ }^{10}$ Our formulation is reminiscent of a popular version of the vintage-capital model, in that each type (vintage) of capital is combined with a certain amount of labor to produce some input into (or, in vintage models: some portion of) final output. As in those models, we could have written the producton function in a more specifically "capital augmenting" way, such as $x_{p}^{i}=\left(L_{p}^{i}\right)^{1-\alpha}\left(A_{p}^{i} K_{p}^{i}\right)^{\alpha}$, but of course with Cobb-Douglas technologies the two formulations are equivalent.

${ }^{11}$ Since differences in disembodied productivity affect all sectors equally, and the model is symmetric in all other respects, endogenizing the investment rate would not change any of the formulas we use in the empirical analysis.
} 
capital types), then in each country all the investment will be concentrated on the highestefficiency type of capital. In contrast, with imperfect substitutability, investors will be willing to hold a diversified portfolio of types, even if the intrinsic efficiency of the various types differ. However, more efficient types will be held in larger proportions. While we do not model the conditions under which the capital is produced (in some foreign country) it is easy to imagine situations where the price of an efficiency unit would vary across types. For example, this will arise if capital is produced under perfect competition, so that price equals marginal cost, and the cost of producing one unit of efficiency differs across types. Alternatively, the degree of monopoly power could vary across equipment producing sectors (in the equipment-producing country). ${ }^{12}$

We can also look at the implications of our assumptions for aggregate income. Using results in the appendix it is possible to write aggregate output as

$$
Y^{i}=B^{i}\left(K^{i}\right)^{\alpha}\left(L^{i}\right)^{1-\alpha}\left[\sum_{p}\left(A_{p}^{i}\right)^{\gamma}\left(\xi_{p}^{i}\right)^{\gamma}\right]^{\frac{1}{\gamma}},
$$

where the last term is an index of the quality of the capital stock. ${ }^{13}$ We can think of this representation as breaking down the contribution of investment to output as a quantity $(K)$ vs. quality (the expression in square brackets) decomposition. Substituting from (2) this decomposition can be alternatively stated as :

$$
Y^{i}=B^{i}\left(K^{i}\right)^{\alpha}\left(L^{i}\right)^{1-\alpha}\left[\sum_{p}\left(A_{p}^{i}\right)^{\frac{\gamma}{1-\gamma}}\right]^{\frac{1-\gamma}{\gamma}} .
$$

The last section of the paper will further discuss this decomposition and the implications of our results for this kind of development-accounting exercise.

\section{Empirical Specification}

The main focus of the empirical analysis is equation (2), where the share of capital of type $p$ in country $i$ 's total capital is related to the efficiency level of type $p$ in country $i$ relative to the efficiency of total capital in country $i$. Our general approach will be to make assumptions on the determinants of the $A_{p}^{i} \mathrm{~s}$, and test these assumptions by estimating equation (2).

\footnotetext{
${ }^{12}$ Below we further comment on the implications of cross-type differences in the price of one efficiency unit for existing work in development accounting and empirical growth.

${ }^{13} \mathrm{It}$ is very tempting to identify the last term in the equation (perhaps multipied by $B$ ) with TFP, but this would not be consistent with the conventional interpretation of TFP. In conventional measures of TFP the capital stock is evaluated - at least in principle - in terms of efficiency units, and not in units of the consumption good (at international prices), as here. Hence, in the model we have written down conventional TFP is just $B$.
} 
Before getting into the details, however, we need to acknowledge a limitation in our ability to map data to theory. Specifically, while we argue that we have fairly accurate information on the composition across equipment types of the dollar value of investments each country makes, we cannot accurately measure the dollar value of the stocks each country has. In order to convert the flows into stocks, we would need both product-specific physical depreciation rates, and product-specific price deflators. The former are available, but the latter are not. ${ }^{14}$ We will therefore proxy for $\xi_{p}^{i}$ using investment in capital of type $p$ as a share of total investment. This would be strictly correct only if there was full depreciation of capital in one year. Though full depreciation in one year is clearly unrealistic, both some robustness checks we performed, and some of the features of our empirical results, lead us to retain confidence in the empirical results we obtain. We explain this in Section 5.

There are $P$ (nine in our case) equations (2), one for each equipment type. Since the $\xi_{p}^{i}$ s sum to one, these equations are linearly dependent. Hence, we divide the equations for types 2 through $P$ by the equation for type 1 , obtaining the $P-1$ equations: $^{15}$

$$
\frac{\xi_{p}^{i}}{\xi_{1}^{i}}=\frac{\left(A_{p}^{i}\right)^{\frac{\gamma}{1-\gamma}}}{\left(A_{1}^{i}\right)^{\frac{\gamma}{1-\gamma}}}, \quad \text { for } p=2, \ldots, P .
$$

It is immediately clear, therefore, that we can only make inferences on the ratios $A_{p}^{i} / A_{1}^{i}$, i.e. on the relative productivity of different types of capital in country $i$. Without loss of generality, therefore, we normalize $A_{1}^{i}=1$.

For the purposes of obtaining an empirical specification, we conjecture that $A_{p}^{i}$ depends on a series of country and product characteristics as follows:

$$
A_{p}^{i}=A_{p} \prod_{c}\left(z_{c}^{i}\right)^{\delta_{c, p}}
$$

In this equation, $A_{p}$ is a product-specific productivity term that applies in all countries (the intrinsic efficiency of this type of capital). $z_{c}^{i}$ is the value of characteristic $c$ in country $i$, and $\delta_{c, p}$ measures the degree of complementarity between equipment of type $p$ and characteristic c. For example, $c$ could be human capital. If $\delta_{c, p}=0$ there is no complementarity between human capital and physical capital of type $p$ : brute force is all that is needed to operate this

\footnotetext{
${ }^{14}$ There do exist quality-adjusted price deflators, i.e. deflators that turn nominal investments into efficiency units. Referring to equation (1) one can think of these deflators as generating an estimate of $\left(A_{p}^{i}\right)^{1 / \alpha} K_{p}^{i}$. (Or, more accurately, since these deflators are available only for the US, $\left(A_{p}^{U S}\right)^{1 / \alpha} K_{p}^{i}$. I.e. they would tell us the amount of type- $p$ efficiency units country $i$ would have if type- $p$ capital was equally productive in country $i$ as in the US.) Since variation across countries and across products is exactly what we want to learn about, it is clear that these deflators would not do. What we would need, instead, are quality-unadjusted deflators, i.e. deflators that convert dollar investments at different dates into current market values.

${ }^{15}$ Notice that $\frac{\xi_{p}^{i}}{\xi_{1}^{i}}=\frac{K_{p}^{i}}{K_{1}^{i}}$. Thus, we refer to the equation in (4) as relative imports equations.
} 
capital. Instead, if $\delta_{c, p}$ is large, $p$ is a highly skill-complementary type of capital. ${ }^{16}$ Because of our normalization, the $\delta$ s capture complementarity between country-characteristic $c$ and capital-type $p$ relative to the complementarity between $c$ and product-type 1 .

Besides human capital, some other possible characteristics $c$ that may complement different capital types differently are: Inward foreign direct investment (FDI) as a share of aggregate investment, where a high $\delta$ would denote a comparative advantage by foreign corporations in importing and installing this type of capital; Outward FDI (as a share of investment), since - as pointed out by Feenstra (1998) - outward FDI may be a mechanism for acquiring intangible assets such as technical knowledge (a high $\delta$ would then indicate that having outward FDI may bring in knowledge which is complementary to this type of capital); The degree of protection of property rights, where a high $\delta$ implies that investing in this type of capital is more profitable when property rights are well protected; ${ }^{17}$ The share of government in GDP, where a high $\delta$ signals that the government has a comparative advantage in operating this type of capital, or a unique demand for this capital; The shares of private GDP accounted for by different sectors, such as services or agriculture, which allows for sector-specificity of the capital types $p$; Measures of financial development, where a high $\delta$ may mean that external financing is comparatively more important for investing in this capital type; Geographical characteristics, that may pick up differences across countries in the relative transport costs of different types of capital. In addition, to partially account for other omitted country characteristics we control for per-capita income.

It may seem odd, particularly to trade economists, that an equation explaining relative imports of a good, be it equipment or otherwise, does not contain variables representing the importing country's abundance in the factors used most intensively to produce that good. A Heckscher-Ohlin-Vanek type of model (e.g., Leamer (1984)) would predict that a country would import relatively more of those goods that tend to be produced by the factor inputs in which the country is scarce (compared to the rest of the world). Our relative imports equation is based on the premise that the types of imported goods we are interested in, namely equipment, cannot be produced domestically by most countries. Such countries do not have those factors (or, perhaps more realistically, those technologies) required to produce equipment and hence these factors play no role in the composition of equipment imports.

\footnotetext{
${ }^{16}$ This discussion assumes that there is a representative worker with the average level of human capital. We explore alternative assumptions below.

${ }^{17}$ Although there are subtle issues of interpretation. If the protection of property rights - particularly intellectual property rights - confers some monopoly power to the would-be importer, the effect on the import share of capital types that are particularly complementary with property-right protection may actually fall. In our empirical work we distinguish between intellectual property rights and property rights more generally.
} 
Substituting (5) and the above normalizations into (4), we get:

$$
\frac{\xi_{p}^{i}}{\xi_{1}^{i}}=\left(A_{p}\right)^{\frac{\gamma}{1-\gamma}} \prod_{c}\left(z_{c}^{i}\right)^{\delta_{c, p} \frac{\gamma}{1-\gamma}} .
$$

One possible reduced-form implementation of this equation is to estimate, separately for each $p$,

$$
\frac{\xi_{p}^{i}}{\xi_{1}^{i}}=\beta_{p} \prod_{c}\left(z_{c}^{i}\right)^{\beta_{c, p}} \varepsilon_{p}^{i}
$$

where $\beta_{p}$ and $\beta_{c, p}$ are parameters to be estimated, and $\varepsilon_{p}^{i}$ is a mean- 1 disturbance. In this specification, the interpretation of $\beta_{p}$ is as $\left(A_{p}\right)^{\frac{\gamma}{1-\gamma}}$, and the interpretation of $\beta_{c, p}$ is as $\delta_{c, p} \gamma /(1-\gamma)$. For each type $p$, these regressions can be estimated with cross-country data on imports relative to type 1 and each of the country characteristics.

A more informative implementation may be to further model the terms $A_{p}$ and $\delta_{c, p}$ as functions of capital type $p^{\prime} s$ characteristics. In particular, both $A_{p}$ and $\delta_{c, p}$ may depend on the amount (or the intensity) of global research and development spending $(R)$ that is embodied in capital-type $p$ (relative to type 1 ). This suggests modeling $A_{p}$ and $\delta_{c, p}$ as functions of $R_{p} / R_{1}$. In other words, the inherent efficiency of capital type $p$ relative to type 1 is a function of the $\mathrm{R} \& \mathrm{D}$ embodied in each type; likewise for the relative complementarity of type $p$ with characteristic $c$. For example, assuming $A_{p}=\left(R_{p} / R_{1}\right)^{\sigma}$ and $\delta_{c, p}=b \log \left(R_{p} / R_{1}\right)$ leads to an estimating equation:

$$
\frac{\xi_{p}^{i}}{\xi_{1}^{i}}=\left(\frac{R_{p}}{R_{1}}\right)^{\phi} \prod_{c}\left(z_{c}^{i}\right)^{\phi_{c} \log \left(R_{p} / R_{1}\right)} \varepsilon_{p}^{i},
$$

where the parameter $\phi$ estimates $\sigma \gamma /(1-\gamma)$ and $\phi_{c}$ estimates $b \gamma /(1-\gamma)$. The parameters $\phi$ and $\phi_{c}$ can be identified from a regression pooling types and countries. Though the parameters in both of the above specifications could be identified with a single year of data, we additionally exploit time variation in order to estimate the parameters more precisely and test whether the intrinsic efficiency of a capital type (in the first specification) or the productivity of $R \& D$ (in the second specification) has changed over time.

The advantage of this second specification is that the coefficients now specifically identify the determinants of import shares as functions of the amount of technology embodied in capital, whereas the constants in the previous specification could be identifying effects on import shares coming from both technology and non-technology causes. The disadvantage, though, is that in the $R \& D$ regression we may be omitting determinants that are not captured by $R \& D$. Furthermore, if the omitted factors are correlated with $R \& D$, we may be assigning the contributions of these omitted factors to $R \& D$.

The choice of estimation technique for equations (7) and (8) is not trivial. A seemingly natural approach would be to take logs on both sides of the equations and use ordinary least 
squares on the resulting linear model. As recently pointed out by Silva and Tenreyro (2003), however, using the log-linear version of multiplicative models has two potentially serious pitfalls. First, if some of the $\xi_{p}^{i}$ s are zero there is a loss of perfectly good information. In addition, the loss of zero observations may potentially lead to sample-selection issues. Second, there is a strong presumption with trade data that the $\varepsilon_{p}^{i} \mathrm{~s}$ will be heteroskedastic, and Silva and Tenreyro show that in this case OLS estimates of the log-linear version of equations such as (7) and (8) can lead to severe bias in the coefficients. Hence, a non-linear method is called for, and these authors' propose a simple pseudo-maximum likelihood approach that performs very well in Monte Carlo experiments. ${ }^{18}$ Pseudo maximum likelihood (PML) will be our method of choice, though we also report on log-linear estimates when they differ substantially from those we obtain by PML.

\section{Data}

Our basic measurement strategy is motivated by evidence that for most countries a very large fraction of the stock of equipment is imported. For these countries, this allows us to measure $\xi_{p}^{i}$, or type- $p$ investment share in total equipment investment, as type- $p$ import share in total equipment import. We obtain these import shares from Feenstra (2000). This data set provides bilateral imports and exports from over 100 countries at a very disaggregated level (generally the 4-digit SITC, Revision 2, level). To construct our investment shares, we first aggregate the bilateral import data across partner countries to get total imports by importing country, for each of the 4-digit commodities. We then identify the 4-digit commodities that correspond to capital goods. Capital-good imports at the 4-digit level are then aggregated (if necessary) into 9 capital-type categories, to match the 9 capital-producing industries for which we have separate R\&D-content data (described below). The nine capitaltype categories are listed and described in Table 1 . The import share $\xi_{p}^{i}$ is imports of type $p$

\footnotetext{
${ }^{18}$ This consists in assuming that the $\varepsilon_{p}^{i}$ s followed a generalized-Poisson distribution - with variance equal to the conditional expectation of the dependent variable - and performing maximum likelihood. To see why this works, here is the GMM interpretation. Given a model $y_{i}=\prod_{k} x_{i k}^{\beta_{k}} \varepsilon_{i}$, the moment conditions are $E\left[\left(y_{i}-\prod_{k} x_{i k}^{\beta_{k}}\right) x_{i k} \mid x_{i 1}, \ldots, x_{i K}\right]=0$ for every $k$. The procedure recommended by Silva and Tenreyro estimates the $\beta_{k} \mathrm{~s}$ by solving the set of equations $\sum_{i}\left(y_{i}-\prod_{k} x_{i k}^{\beta_{k}}\right) x_{i k}=0$, and is therefore equivalent to applying the method of moments by giving equal weight to all observations. This is the optimal GMM weighting scheme in the special case where $\operatorname{Var}\left(\varepsilon_{p}^{i} \mid x_{i 1}, \ldots, x_{i k}\right)=E\left(y_{i} \mid x_{i 1}, \ldots, x_{i k}\right)$, but the authors show that it continues to perform very well for a wide variety of alternative assumptions. In contrast, the more standard non-linear least squares estimator solves the system of equations $\sum_{i}\left(y_{i}-\prod_{k} x_{i k}^{\beta_{k}}\right) x_{i k} \prod_{k} x_{i k}^{\beta_{k}}=0$, i.e. it gives more weight to observations with a high conditional expectation for the dependent variable. Since high values for the dependent variable are typically associated with high variance, this is equivalent to giving more weight to more noisy observations. Consistent with this, non-linear least squares turns out to be much less efficient than Poisson maximum likelihood in Monte Carlo experiments.
} 
divided by total capital imports (note that this differs from total imports).

Data on R\&D by industry, for the 15 primary R\&D-performing countries in the world, are provided in the ANBERD database maintained by the OECD. ${ }^{19}$ According to Coe and Helpman (1995), these 15 countries account for roughly $90 \%$ of the world R\&D expenditures. A subset of nine of the industries in the $R \& D$ database are capital-good producers. To construct "world" R\&D flows by capital-type $(p)$, we aggregate $\mathrm{R} \& \mathrm{D}$ spending (in constant US dollars) across all countries by capital-good-producing industry. We then construct world R\&D stocks by capital-type using a perpetual inventory accumulation of past flows and a depreciation rate of $15 \% .{ }^{20}$ Besides the R\&D stock, in our empirical work we also experiment with two alternative measures of $R \& D$ intensity by capital-type. The first, which we call the "R\&D flow intensity," is the world R\&D flow into an equipment type divided by total sales of that type by the same 15 R\&D-performing countries. The second measure, "R\&D stock intensity," is the R\&D stock divided by total sales. The sales data are from the UNIDO Industrial Statistics Database. The time span of overlapping coverage between the Feenstra, ANBERD, and UNIDO data sets is 1980 to 1997.

The means and standard deviations, by capital-type, of the capital (equipment) import shares are shown in Table 2, for two "representative" years. Also shown are the correlations between each equipment type's import share and real GDP per capita. We report separate statistics for the full sample of countries for which we have both capital-import and GDP per capita data, and for the sample we use in our relative imports regressions below. This latter sample consists of countries with data on all of the country characteristics we analyze and excludes the 15 R\&D-performing countries. According to the evidence presented by Eaton and Kortum (2001), identification of imports with investment is most legitimate these non-R\&D-performing countries.

The most important thing to note is that the standard deviations of the import shares are quite large relative to the means. The coefficients of variation (standard deviation divided by mean) are especially large for aircraft, other transportation equipment, and computers. These large coefficients of variation document that there is a great deal of cross-country variation in the composition of capital. Looking at the raw correlations with per-capita income, it appears that poorer countries' capital stocks tend to have larger shares of fabricated metal products, non-electrical equipment, and other transportation equipment. Rich countries' investments, instead, are more skewed towards computing and accounting machinery, electrical and communication equipment, and professional goods.

\footnotetext{
${ }^{19}$ The 15 countries are Australia, Canada, Denmark, Finland, France, (unified) Germany, Ireland, Italy, Japan, Netherlands, Norway, Spain, Sweden, Great Britain, and USA.

${ }^{20}$ We initialize the R\&D stock in 1973 as the 1973 R\&D flow divided by the depreciation rate. The choice of a 15 percent depreciation rate is standard in the literature on R\&D stocks.
} 
An alternative method for identifying investment shares is to measure investment (by type) as imports minus exports plus gross domestic output. Data on exports by type are available from Feenstra (2000) while data on gross domestic output of each equipment type can be gleaned from the UNIDO data set. Unfortunately, the UNIDO data is much more limited in country coverage than our other data, leading to too small of a sample size for meaningful empirical work. Nevertheless, the investment shares computed combining the import data with production and export data tend to convey a roughly similar impression of high variance across countries. More importantly, as documented in Figure 1, the investment shares computed as imports plus output minus exports are highly correlated with the import shares we use in our regressions, especially for non-R\&D performing countries.

Aside from statistics characterizing import shares, Table 2 also shows the values in 1980 and 1995 of the three measures of embodied R\&D. It is also notable that the three measures of embodied R\&D roughly agree on the ordering of capital types by embodied technology, especially in 1980. While this ordering has changed somewhat over time, the capital types which tend to embody the most R\&D are consistently aircraft, communications equipment, computers, and professional goods, while fabricated metal products and nonelectrical machinery seem to embody the least.

Data on country characteristics are obtained from a variety of sources. Our measure of human capital is based on average years-of-education data from Barro and Lee (2001). Following Hall and Jones (1999), we construct an index of human capital as $z_{H C}^{i}=e^{\phi\left(E^{i}\right)}$ where $E^{i}$ denotes country $i$ 's average years of schooling for the population 25 or over. $\phi^{\prime}\left(E^{i}\right)$ is the return to a year of schooling. We use the values for $\phi^{\prime}\left(E^{i}\right)$ from Hall and Jones, which in turn are based on Mincerian wage regressions from different regions of the world. ${ }^{21}$ Foreign direct investment, inward and outward, is from Lane and Milesi-Ferretti (2001). We look at two measures of property-right protection, one narrow, limited to intellectual property right protection (IPR), and the other broad, covering property rights in general. The former is an index compiled by Ginarte and Park (1997), while the latter is from various editions of the Fraser Institute's "Economic Freedom of the World." The sectorial composition of GDP (by industry and by government share) is from the World Bank's World Development Indicators, and so is our measure of financial development (M3 money supply as a fraction of GDP). To account for geographic characteristics that may induce type-specific transport cost differences we obtain an index of "remoteness" (essentially, geographical distance from the "rest of the world," where distances to other countries are weighted by GDP) from Silva and Tenreyro (2003). GDP per capita and aggregate investment (used to scale the FDI variables) are from

\footnotetext{
${ }^{21}$ The Hall and Jones specification, in particular, is $\log \left(z_{H C}^{i}\right)=(0.134) E^{i}$ if $0<E^{i} \leq 4 ; \log \left(z_{H C}^{i}\right)=$ $(0.134)(4)+(0.101)\left(E^{i}\right)$ if $4<E^{i} \leq 8$; and $\log \left(z_{H C}^{i}\right)=(0.134)(4)+(0.101)(4)+(0.068)\left(E^{i}\right)$ if $8<E^{i}$.
} 
the Penn World Tables, Mark 6.0 [Summers and Heston (2002)]. Table 3 shows the means and standard deviations, for 1980 and 1995, of the country-characteristic variables we use in our empirical work. The statistics are computed using the regression sample we use for the relative imports regression below. ${ }^{22}$

The final data set is three dimensional. The panel is balanced in the capital-type dimension, but unbalanced in the year and country dimensions. The range of the year dimension is the 5-year intervals 1970-1995. We restrict our panel to 5-year intervals because many of the country characteristics are relatively slow moving over time. This recommends that we try to rely most heavily on cross-country variation to identify our parameters. There are between 38 and 40 countries in the panel, depending on which variables are to be included. This panel excludes the 15 R\&D-performing countries because, as explained above, the correspondence between investment composition and import composition is best outside of these countries. Nevertheless, we did check to see if the regression results reported below are robust to including these countries. They are. In fact, the results change very little except the significance levels of a number of coefficients is increased, which is likely explained simply by the added number of observations.

Finally, note that though the observations in our panel have three dimensions, the only variables that vary by equipment type are $R \& D$ (which varies by type and year, but not country) and the capital import shares (which vary by all three dimensions).

\section{$5 \quad$ Estimation Results}

\subsection{Type-by-Type Specification}

In this sub-section we report the coefficients obtained by estimating equation (7) for each capital type. One of the nine types must act as numeraire, and we choose "Fabricated Metal Products" (ISIC 381) because Table 3 suggests this to be the type of capital that embodies the least amount of technology. Two of the three measures of R\&D content rank this type last and the other measure ranks it second to last. Because equipment import is a better proxy for investment in the group of countries that excludes the $R \& D$ performers, all our regressions are run on this sub-sample only.

The results are reported in Table 4. Panel A contains a baseline specification including a constant, the index of protection of intellectual property rights (IPR), human capital, inward and outward FDI, the government share in GDP, as well as the shares of industry (manufacturing, plus construction, mining, and utilities) and services. The baseline specification also includes the "catch-all" control of per-capita GDP (in logs) and a time trend. Panels

\footnotetext{
${ }^{22}$ Specifically, we use the sample used in the final specifications of Tables 4 and 5 .
} 
B, C, and D further enrich the baseline specification by adding, incrementally, the measure of geographic remoteness, the proxy for financial development, and the broader measure of property-right protection. Panel E repeats the final specification of panel D but breaks down human capital into three skill levels: the proportion of the population with at most a primary degree, those with a primary degree but at most a secondary one, and those who went beyond high school (the latter being the omitted category).

Not surprisingly, as we add controls we lose precision in the estimates. This is partly because the number of coefficients to be estimated increases. Mostly, however, the loss of precision is due to the fact that the additional controls cover fewer countries and (especially) fewer periods, so that the overall sample size is considerably reduced. We will therefore emphasize results from Panel A, and comment on their robustness across other panels.

Recall that according to our model the constant term captures type-specific (and not country-varying) differences in inherent efficiency (relative to fabricated metal products). There is very robust evidence of intrinsic inefficiency for computing and accounting equipment, electrical equipment, communication equipment, and professional goods: for these equipment types the constant is significantly negative in all specifications. This result may appear puzzling at first sight, as these are all the "high-tech" products, but it can easily be rationalized in the context of our model. In particular, these capital goods may actually be less productive than metal products when one pulls out their complementarities with human capital, FDI, IPR, etc.. In other words, a country with the minimum levels of human capital, FDI, IPR, etc. may get more productive use out of hand tools, general hardware, and the other kinds of basic capital goods contained within the "Metal Products" type, than out of these other types which may require substantial complementary investments and/or endowments. $^{23}$

Interestingly, however, investment shares in the same group of equipment types show substantial positive time trends, suggesting that those complementarities have eroded over time.

Inward FDI robustly predicts lower investments in non-electrical equipment (relative to metal products) and higher investments in communication equipment. Less robustly, it also has some predictive power for higher investments in electrical equipment, and transportation

\footnotetext{
${ }^{23} \mathrm{An}$ alternative interpretation is that there is a high degree of homogeneity of capital goods within these categories relative to that of metal products. Our model is predicated on the assumption that each capital type is a homogenous good and is used in the production of a homogenous input into the production of final output. Therefore each capital type has diminishing returns to scale, dictated by the parameter $\gamma$. If in fact a type category contains many varieties of capital goods, as is likely for metal products, it will not suffer the same degree of diminishing returns and will therefore be demanded in larger quantities. One could think of the degree of heterogeneity, or variety, in a capital-type as a feature of its intrinsic quality.
} 
equipment other than motor vehicles and aircraft. Outward FDI has exactly symmetrical implications: higher imports of non-electrical equipment, and (less robustly) lower imports of electrical equipment and "other" transportation equipment. The government consumption share in GDP is fairly robustly negatively associated with non-electrical equipment, and also appears to have some positive correlation with other transport equipment. The share of industry in GDP always positively predicts relative investments in non-electrical equipment, and negatively communication equipment. Remoteness clearly increases relative investment in office and computing equipment, and (most appropriately) communications equipment and other transportation equipment. Financial development appears to be important for investment in electrical equipment, and the broad measure of property right protection for aircraft investment.

A very surprising result is that human capital is almost never a significant factor in determining the relative share of investment in a particular type of capital. This result is in strong conflict with a wealth of recent evidence that there is a high degree of complementarity between human capital and certain new technologies, such as computers. It is also at odds with previous empirical studies of technology diffusion. Splitting the human capital variable into various skill categories does not affect this result. Another variable that is surprisingly unable to predict relative investments is the service share in GDP (agriculture is the omitted sector). The protection of intellectual property rights has also no robust predictive power for any of the investment shares, though it may play some (negative) role in relative nonelectrical equipment imports. Real income per capita is also mostly insignificant (except for aircraft in Panel E), which is prima facie evidence that there are no further key omitted variables.

When we estimate the same set of regressions using Ordinary Least Squares instead of Pseudo Maximum Likelihood we obtain very similar results. The main differences are in the estimates for aircraft investment, on which intellectual property right protection and inward FDI exert negative influences, and human capital and outward FDI positive ones. None of these variables were significant for aircraft investment when using PML. Another difference is that inward FDI no longer predicts higher investments in communication equipment.

\subsection{Embodied R\&D Specifications}

In this section we pool together the investments in all equipment types (always relative to metal products) to estimate equation (8). The explanatory variables, therefore, are an equipment type's R\&D content, as well as a set of interaction terms between R\&D content of the type and characteristics of the importing country. The results are reported in Table 5 , where we estimate five specifications exactly analogous - in terms of the list of country 
characteristics progressively included - to the five type-by-type specifications of the previous subsection. The embodied $R \& D$ measure used in these regressions is the $R \& D$ flow intensity - i.e. worldwide current R\&D spending divided by worldwide sales. It turned out that the results were not at all sensitive to the choice of the $R \& D$ variable. ${ }^{24}$ Collectively these $R \& D$ regressions exploit fewer country-year data points than the type-by-type analogs because the data on output by equipment-producing industry, the denominator in R\&D intensity, begins in 1980. However, this disadvantage is compensated by the fact that pooling across capital types increases the number of observations by a factor of 8 .

In the final specification including all of the explanatory variables the log of an equipment type's relative R\&D intensity is negatively associated with that type's investment share (always relative to metal products). This is consistent with the evidence in the previous subsection, where equipment types we intuitively associate with high technology appeared to feature relatively low intrinsic efficiency (as implied by the negative constant terms). The likely explanation, once again, is that high technology is complementary with other inputs or institutions. When R\&D intensity is entered by itself the coefficient captures the efficiency of high tech capital in a country with low levels of these complementary country characteristics, and it is therefore not surprising that it would be negative. The positive coefficient on the interaction term between R\&D-intensity and a time trend, on the other hand, suggests that even in countries with low levels of the R\&D-complementary characteristics the efficiency of R\&D intensive capital has increased over time.

All of the other explanatory variables are interactions of $R \& D$ intensity with country characteristics. The coefficient on the interaction between R\&D intensity and inward FDI is robustly negative. In other words, FDI flows skew the composition of the capital stock towards low-tech types of equipment. This is somewhat surprising, and defies much common wisdom. In particular, FDI is often cited in policy circles as a key vehicle for technology transfer. Our results are inconsistent with this view. However, they are consistent with the view that FDI signals outsourcing of the production of low-tech goods to countries with cheap inputs. Furthermore, notice that - even if it does not affect high-technology transfer - FDI may still be highly beneficial to recipient countries if it increases the overall capital stock.

Another variable whose interaction with $R \& D$ content has robust predictive power for investment shares is remoteness: far away places import a relatively larger share of high-tech (or at least high R\&D) equipment. The likely explanation for this finding is that high-tech equipment is "lighter," in a physical weight per dollar sense, so that remote locations will have a disproportionate demand for them. It may also be that remote countries demand relatively more computers and, of course, communications equipment (both high in $R \& D$ )

\footnotetext{
${ }^{24}$ Results using the R\&D stock or the $R \& D$ stock intensity are availble from the authors upon request.
} 
to conduct business with other countries. Remote countries may also require more aircraft (also high in R\&D) to trade goods and engage in face-to-face business with those in other countries.

Another robust result seems to be that a broad measure of property rights protection interacts positively with the R\&D intensity of the types of equipment a country invests in. Perhaps high technology products are more costly to protect from looting, theft, or expropriation. It could also be that aircraft are driving this result: aircraft are very $\mathrm{R} \& \mathrm{D}$ intensive and property rights may be quite important for goods as expensive as aircraft. Another explanation might have been that $R \& D$ intensive equipment is complementary with software and other intellectual products, but it also turns out that the IPR index is not robustly associated with the investment share of $R \& D$ intensive capital.

Other variables afford more ambiguous insights. Outward FDI may be associated positively with the $R \& D$ intensity of imports, but this result does not hold in all specifications. There is also some not entirely robust evidence of complementarities between R\&D intensity and both industrial share and services share in GDP, while there is evidence of a negative R\&D-government share complementarity. Financial development plays no significant role, and real per-capita income is not significant in the final specification, perhaps indicating that we are not omitting some important determinant of a country's capital composition.

Among the variables that do not interact significantly with $R \& D$ intensity in determining a country's investment composition, human capital continues to be the most surprising. Except for the first column, where the coefficient is large and significant, the R\&D human capital interaction is not significantly different from zero. The loss in significance may be driven by the addition of further explanatory variables, or - more likely - by the fact that the sample size falls by one third when we add these additional controls. More importantly, however, our surprising human-capital result is reversed when we break up the labor force into those with no secondary education, those with only secondary education, and those with some tertiary education (the latter being the omitted group). The last column shows clear evidence of complementarity between tertiary education and R\&D intensity of investment (because the coefficients on secondary and no secondary are negative). Hence, when all is said and done, our results are still consistent with a version of technology-skill complementarity.

Before concluding the discussion of our empirical estimates of equations (7) and (8) we briefly revisit the question of how well do investment shares proxy for capital shares. We make two points. First, we computed a crude measure of stocks of imported equipment via a perpetual inventory of past equipment imports, using depreciation rates derived from US. data, and assuming that equipment prices remained constant over our sample period. 
The regression results using these stocks were quite similar to those we have just reported. Second, the patterns of coefficients we obtain in our regressions are inconsistent with serious biases from using investment flows as proxies for stocks. High-tech capital types, such as computers, are likely to have higher depreciation rates than low-tech types, such as hand tools. Hence, assuming 100\% depreciation will lead to an especially large underestimate of low-tech capital. In our type-by-type regressions, this would lead us to underestimate the intercept for low-tech capital types, and overestimate the intercept for high-tech capital. However, what we find is low intercepts for high-tech equipment types! Furthermore, the relative underestimation of low-tech capital, and overestimation of high-tech capital, will be worse for countries that are late (relative to the observation year) adopters of high-tech capital. If late adopters of high-tech capital have low values for our country characteristics, the coefficients on these characteristics will be biased towards zero. We conclude that our results would likely only become more pronounced if dollar-value equipment stocks could be more accurately measured.

The only substantive difference when using OLS is that the coefficient on the government share in GDP is never significantly different from zero.

\section{Implications for Development Accounting}

Until now we have endeavored to identify the cross-country determinants of imports of capitalembodied technology. We have found that there are a number of country-specific factors that have a significant effect on the demand for capital of different types. In particular, these country-specific inputs and institutions affect the $R \& D$ content of the types of capital a country invests in. In this section we try to address the obvious question: does it matter for explaining productivity differences across countries?

The simple model we laid out in Section 2 suggests that the answer should be yes. In that section, we derived the equation

$$
Y^{i}=B^{i}\left(K^{i}\right)^{\alpha}\left(L^{i}\right)^{1-\alpha}\left[\sum_{p}\left(A_{p}^{i}\right)^{\gamma}\left(\xi_{p}^{i}\right)^{\gamma}\right]^{\frac{1}{\gamma}},
$$

which suggests that differences in the composition of the stock of equipment, i.e. in the vector of the $\xi \mathrm{s}$, could have explanatory power for cross-country differences in output - unless, that is, equipment of different types embodies identical amounts of technology. This section has two objectives. First, we discuss the implications of our model, as well as of our empirical results, for existing development accounting exercises. Second, we present a first-pass attempt at an empirical implementation of equation (9), aimed at assessing the potential role of imported embodied technology in explaining cross-country variation in output per worker. 


\subsection{Heterogeneous Capital and Development Accounting}

Following standard practice we can rewrite (9) as

$$
y^{i}=B^{i}\left(\frac{K^{i}}{Y^{i}}\right)^{\frac{\alpha}{1-\alpha}}\left[\sum_{p}\left(A_{p}^{i}\right)^{\gamma}\left(\xi_{p}^{i}\right)^{\gamma}\right]^{\frac{1}{\gamma(1-\alpha)}}
$$

where $y^{i}$ is real per-worker GDP in country $i$ (i.e. $y_{i}=Y_{i} / L_{i}$ ). The typical growth-accounting exercise starts by positing the relationship

$$
y^{i}=B^{i}\left(\frac{\tilde{K}^{i}}{Y^{i}}\right)^{\frac{\alpha}{1-\alpha}}
$$

where $\tilde{K}$ is a measure of the real (read quality-adjusted) capital stock. Recall that, instead, in (10) $K^{i}$ is the dollar value of the capital stock. Given a measure of $\tilde{K}^{i}$, in development accounting one proceeds to estimate or calibrate $\alpha$, and to then make inferences on the relative importance of capital and disembodied TFP (the term $B$ ) in causing cross-country income differences.

One first implication - which is immediately obvious by comparing the two equations -

is that for those inferences to be correct it has to be the case that $\tilde{K}^{i}=K^{i}\left[\sum_{p}\left(A_{p}^{i}\right)^{\gamma}\left(\xi_{p}^{i}\right)^{\gamma}\right]^{\frac{1}{\alpha \gamma}}$. Now the particular way $\tilde{K}^{i}$ is usually measured in this literature is as the price-weighted sum of investments in various types of equipment, or

$$
\tilde{K}^{i}=K^{i} \sum_{p} \xi_{p}^{i} / P_{p}^{i}
$$

where $P_{p}^{i}$ is the price of equipment of type $p$. Clearly, then, there is an underlying implicit assumption that (i) $\gamma=1$, i.e. different types of capital are perfect substitutes, and (ii) $P_{p}^{i}=1 / A_{p}^{i}$, i.e. country-specific prices for capital of type $p$ fully reflect the country-specific efficiencies of this type. ${ }^{25}$ Clearly assumption (i) is not appealing (computers and trucks are probably not perfect substitutes). ${ }^{26}$ Assumption (ii) is also unappealing: as discussed

\footnotetext{
${ }^{25}$ It may seem that even if the two assumptions hold, there is still a problem with the term $1 / \alpha$ in the exponent. This is true but we don't emphasize this because this term is somewhat model specific. For example, had our model been$$
Y^{i}=B\left(L^{i}\right)^{1-\alpha}\left[\sum_{p=1}^{P}\left(x_{p}^{i}\right)^{\gamma}\right]^{\frac{\alpha}{\gamma}}, \quad x_{p}^{i}=A_{p}^{i} K_{p}^{i}
$$

the condition for the standard exercise to deliver correct inferences would simply be $\tilde{K}^{i}=$ $K^{i}\left[\sum_{p}\left(A_{p}^{i}\right)^{\gamma}\left(\xi_{p}^{i}\right)^{\gamma}\right]^{\frac{1}{\gamma}}$, which only requires (i) and (ii).

${ }^{26}$ That measuring a capital aggregate from a set of subaggregates, all in terms of efficiency units, requires perfect substitutability was proven in Fisher (1983): “[t]he use of subaggregates like 'equipment' and 'plant'
} 
in Section (2), if $\gamma<1$ there is no reason to believe that prices per unit of efficiency will be equalized across equipment types. Furthermore, even if $P_{p}^{i}$ is measured using techniques designed to capture quality (e.g., hedonic regressions), it is very unlikely to capture the country-specific differences in efficiency of type $p$ that our empirical results seem to uncover. ${ }^{27}$ Thus, given the inappropriateness of (i) and (ii) above, inferences on the relative contribution of capital and disembodied TFP based on $\tilde{K}^{i}$ are likely to be misleading.

Even if one believed the bias introduced by the mis-measurement of $\tilde{K}^{i}$ to be small or second order, though, there would still be reason to implement a more disaggregated view of capital. Such a view makes it possible to investigate the sources of the explanatory power of real capital for development levels. Do high $Y^{i}$ countries have high $\tilde{K}^{i}$ because they save a lot, or because they invest in types of capital with particularly high levels of embodied technology? Or is it that they invest in those types of capital that are especially complementary with their factor endowments? It is easy to imagine that answers to questions like these - that can really be fully explored by disaggregating the capital stock - can have profound implications for development policy. ${ }^{28}$

In conclusion, implementing equation (10) instead of equation (11) may provide a set of insights that are both more accurate and richer about the sources of cross-country differences in development.

\subsection{A First-Pass Implementation}

Implementing a development-accounting exercise based on equation (10) obviously requires knowledge of the vector of country-specific efficiency parameters $A_{p}^{i}$. But the $A_{p}^{i}$ s are exactly the objects we tried to estimate in the first part of the paper. In particular, given a set of country characteristics $z_{c}^{i}$, we have assumed $A_{p}^{i}=A_{p} \prod_{c}\left(z_{c}^{i}\right)^{\delta_{c, p}}$, and estimated the parameters $A_{p}$ and $\delta_{c p}$. We can therefore plug these numbers in equation (10), together with the observed $\xi_{p}^{i} \mathrm{~s}$, and ask what fraction of the overall variance of income per worker does our capitalcomposition term explain. More specifically, after defining $Q_{i}(\gamma, \alpha)=\left[\sum_{p}\left(A_{p}^{i}\right)^{\gamma}\left(\xi_{p}^{i}\right)^{\gamma}\right]^{\frac{1}{\gamma(1-\alpha)}}$ the "quality" of country $i$ 's capital stock, we can compute for different choices of $\alpha$ and $\gamma$ the

together with an aggregate 'capital' thus implies that 'plant' and 'equipment' are perfect substitutes and is highly questionable." Fisher showed that this result holds for any continuous, twice-differentiable production function.

${ }^{27}$ Many national statistical agencies simply adopt the U.S.'s hedonic computer deflator for their own, but if the efficiency of computers is country specific this practice is inappropriate.

${ }^{28} \mathrm{On}$ some of these questions it is actually possible to make some progress without disaggregating the capital stock. For example, Hsieh and Klenow (2002) decompose $\tilde{K}$ into a component due to savings and one due to price levels of investment goods, and find that most of the explanatory power of $\tilde{K}$ comes from prices. 
fraction of income variance explained by capital quality as

$$
\frac{\operatorname{Var}\left\{\log \left[Q_{i}(\alpha, \gamma)\right]\right\}}{\operatorname{Var}\left[\log \left(y_{i}\right)\right]} .
$$

As an alternative measure less affected by outliers, one can also look at the inter-percentile range, i.e. the ratio of the 90 th to the 10 th percentile of the distribution of $Q$, divided by the analogous ratio for the distribution of $y .^{29}$

In Section 2 we also noted that, with additional assumptions on the inter-sectorial mobility of labor and capital, we can rewrite $Q_{i}(\gamma, \alpha)$ as $Q_{i}^{\prime}(\alpha, \gamma)=\left[\sum_{p}\left(A_{p}^{i}\right)^{\frac{\gamma}{1-\gamma}}\right]^{\frac{1-\gamma}{\gamma(1-\alpha)}}$. Hence, an alternative implementation would use exclusively the estimated $A_{p}^{i} \mathrm{~s}$, and choices of $\alpha$ and $\gamma$, to compute the variance of income due to variance in capital quality.

Finally, we note that in the first half of the paper we have estimated the $A_{p}^{i} \mathrm{~s}$ in two ways: with type-by-type regressions in which $A_{p}$ and the parameters $\delta_{c p}$ were constant, and with embodied R\&D regressions in which $A_{p}$ and $\delta_{c p}$ where functions of the R\&D content of capital of type $p$. Hence, our proposed decomposition can be performed four ways: two ways of computing quality (using only the $A_{p}^{i} \mathrm{~s}$ or also the $\xi_{p}^{i} \mathrm{~s}$ ), and two ways of estimating $A_{p}^{i}$.

Before presenting the results, it is worth making a few additional comments on the nature of this exercise. First, even if the distribution of $Q$ turns out be highly dispersed, so that quality "explains" a reasonably large fraction of the output variance, it may be that the correlation between $Q$ and $y$ is low. To address this concern we also report these correlations. Second, we have essentially argued that $\left(\frac{K^{i}}{Y^{i}}\right)^{\frac{\alpha}{1-\alpha}} Q_{i}(\alpha, \gamma)$ is a better measure of "quality-adjusted" capital intensity than $\left(\frac{\tilde{K}^{i}}{Y^{i}}\right)^{\frac{\alpha}{1-\alpha}}$, which is what is featured in the existing literature. It would be highly desirable, therefore, to be able to measure the term $K^{i} / Y^{i}$, and compare our quality-adjusted capital intensity to the standard (incorrect) one. In particular, we would like to know if our quality-adjustment allows us to explain a larger fraction of the variance of income. Unfortunately, however, for reasons already discussed in Section (4), we do not have measures of the market value of the capital stock, $K^{i}$. This "horse race," therefore, will have to await for better data.

Third, by focusing exclusively on variation in $Q_{i}$, we are attributing all of the remaining variation in incomes to the term $B^{i}\left(\frac{K^{i}}{Y^{i}}\right)^{\frac{\alpha}{1-\alpha}}$. However, to the extent that this residual term covaries with $Q_{i}$, it may be legitimate to assign some of the covariance to the latter. For example, Klenow and Rodriguez-Clare (1997) compute the fraction of the variance in per-capita income explained by the observables, as the variance of the observables plus half

\footnotetext{
${ }^{29}$ See Caselli (2003) for a discussion of this approach to development accounting. In this section we use the full sample - including the $15 \mathrm{R} \& \mathrm{D}$ producing countries. However, the estimated $A_{p}$ and $\delta_{c p}$ continue to be those obtained in Section 5 from the non R\&D-performing sample. We perform these calculations to data from the year 1990 .
} 
of the covariance between observables and unobservables. From this perspective, therefore, we are reporting lower bounds on the fraction of the income variance explained by capital quality.

Our tentative decomposition results are reported in Table 6. In all experiments we hold $\alpha$ constant at 0.33. For $\gamma$, we try three different values: $0.25,0.5$, and 0.75 . Also, for both the type-by-type and $\mathrm{R} \& \mathrm{D}$ regressions, we must decide on a particular specification to obtain $A_{p}^{i}$. We use the final, "full" specification of Tables 4 and 5.

In all cases our measure of the quality of capital shows a solid positive correlation with per-capita income. Figure 2 shows some of these correlations graphically. Unfortunately, however, it turns out that our measures of the amount of income variance explained by capita quality is exceedingly sensitive to the value of $\gamma$ used. In fact, by choosing a suitably low value for $\gamma$ it is possible to explain all of the variation in income with capital quality alone. The intuition is that, as we have seen, the vector of investment shares $\xi$ varies tremendously across countries. Clearly, then, the less substitutable the capital types (the lower $\gamma$ ), the larger the effect of capital-composition on income differences. An additional shortcoming of the results is that the amount of variation explained is very sensitive to the measure of dispersion we use, with the inter-percentile range generally implying that capital quality explains a larger fraction of the variation in the data. These differences in results are clearly attributable to our small sample size.

While these highly unstable results make it difficult to draw a clear conclusion, they at least suggest that capital-composition effects (what we called the quality of capital) have potential in enhancing our ability to account for cross-country income differences. Suppose they could account for 10 percent of the overall variance - a number that seems at least not implausible based on the evidence in Table 6. Development-accounting exercises using the standard measure of the real capital stock (that tries to account for both quality and quantity), as well as a measure of human capital, are typically unable to explain much more than 50 percent of the overall income variance. 10 percent attributable to capital-quality alone would be a large fraction of that!

\section{Conclusions}

Disaggregating capital into separate quantity and quality terms could be important for development accounting. When capital types are heterogeneous (perhaps because of differences in embodied technology), attempting to measure a single quality-adjusted capital aggregate requires the implausible assumptions that (i) all capital goods are perfectly substitutable; and (ii) measured prices of capital types reflect country-specific efficiencies. The results in this paper cast serious doubt on both of these assumptions. 
First, the perfect substitutability between capital types is inconsistent with the tremendous variation in capital composition both within and across countries. Secondly, when we estimate our empirical model of capital import shares, we find not only that capital types differ greatly in terms of intrinsic efficiency (further casting doubt on (i)), but also that country-specific factors substantially affect the efficiency, and therefore the demand, of capital types (casting doubt on (ii)). In particular, college-level skills, the degree of property rights protection, and a country's remoteness from the rest of the world are complementary with high-technology equipment types. Inward FDI is complementary with low-technology types.

\section{References}

[1] Acemoglu, Daron, and Fabrizio Zilibotti. "Productivity Differences." Quarterly Journal of Economics 116, no. 2 (2001): 563-606.

[2] Aghion, Philippe, and Peter Howitt. Endogenous Growth Theory. Cambridge, MA: MIT Press, 1998.

[3] Barro, Robert J., and Xavier Sala-i-Martin. Economic Growth. New York, NY: McGrawHill, 1995.

[4] Basu, Susanto, and David N. Weil. "Appropriate Technology and Growth ." Quarterly Journal of Economics 113, no. 4 (1998): 1025-54.

[5] Caselli, Francesco, and John Coleman. "Cross-Country Technology Diffusion: The Case of Computers." American Economic Review Papers and Proceedings, May 2001.

[6] Caselli, Francesco, and Wilbur John Coleman II. "The World Technology Frontier." NBER Working Paper 7904 (2002).

[7] Coe, David T., and Elhanan Helpman. "International R\&D Spillovers." European Economic Review 39, no. 5 (1995): 859-87.

[8] Diwan, I., and Dani Rodrick. "Patents, Appropriate Technology, and North-South Trade." Journal of International Economics (1991).

[9] Eaton, Jonathan, and Samuel Kortum. "Trade in Capital Goods." European Economic Review 45, no. 7 (2001): 1195-235.

[10] Feenstra, Robert C. "World Trade Flows, 1980-1997." Mimeo (2000). 
[11] Fisher, Franklin M. "On the Simultaneous Existence of Full and Partial Capital Aggregates." Review of Economic Studies 50, no. 1 (1983).

[12] Gera, Surendra, Wulong Gu, and Frank C. Lee. "Information Technology and Labour Productivity Growth: An Empirical Analysis for Canada and the United States." Canadian Journal of Economics 32, no. 2 (1999): 384-407.

[13] Ginarte, Juan C., and Walter G. Park. "Determinants of Patent Rights: A CrossNational Study." Research Policy 26, no. 3 (1997): 283-301.

[14] Greenwood, Jeremy, Zvi Hercowitz, and Per Krusel. "Long-Run Implications of Investment-Specific Technological Change.” American Economic Review 87, no. 3 (1997): $342-62$.

[15] Grossman, Gene, and Elhanan Helpman. Innovation and Growth in the Global Economy. Cambridge, MA: MIT Press, 1991.

[16] Hall, Robert E., and Charles I. Jones. "Why Do Some Countries Produce So Much More Output Per Worker Than Others?" Quarterly Journal of Economics (1999): 83-116.

[17] Hendricks, Lutz. "How Important Is Human Capital for Development? Evidence From Immigrant Earnings ." American Economic Review 92, no. 1 (2002): 198-219.

[18] Heston, Alan, Robert Summers, and Bettina Aten. "Penn World Table Version 6.1." Center for International Comparisons at the University of Pennsylvania (CICUP) (2002).

[19] Hsieh, Chang-Tai, and Peter J. Klenow. "Relative Prices and Relative Prosperity." Mimeo (2002).

[20] Hummels, David, and Peter J. Klenow (2002): "The Variety and Quality of a Nation's Trade," NBER WP 8712.

[21] Hulten, Charles R. "Growth Accounting When Technical Change Is Embodied in Capital." American Economic Review 82, no. 4 (1992): 964-80.

[22] Jorgenson, Dale W., Frank M. Gollop, and Barbara M. Fraumeni. Productivity and U.S. Economic Growth. Cambridge, MA: Harvard University Press, 1987.

[23] Jovanovic, Boyan, and Rafael Rob. "Solow Vs. Solow." Working Paper, New York University (1997).

[24] Klenow, Peter J., and Andres Rodriguez-Clare. "The Neoclassical Revival in Growth Economics: Has It Gone Too Far?" NBER Macroeconomics Annual (1997). 
[25] Keller, Wolfgang. "The Geography and Channels of Diffusion at the World's Technology Frontier." NBER Working Paper 8150 (2001).

[26] Keller, Wolfgang. "International Technology Diffusion," unpublished, University of Texas.

[27] Lane, Philip R., and Gian Maria Milesi-Ferretti. "The External Wealth of Nations: Measures of Foreign Assets and Liabilities for Industrial and Developing Countries." Journal of International Economics 55, no. 2 (2001): 263-94.

[28] Leamer, Edward E. Source of Comparative Advantage. Cambridge, MA: MIT Press, 1984.

[29] Mankiw, N. Gregory, David Romer, and David N. Weil. "A Contribution to the Empirics of Economic Growth." Quarterly Journal of Economics 107, no. 2 (1992): 407-37.

[30] Parente, Stephen L., and Edward C. Prescott. "Barriers to Technology Adoption and Development." Journal of Political Economy 102, no. 2 (1994): 298-321.

[31] Solow, Robert M. "Investment and Technical Progress." Mathematical Methods in the Social Science. Editors Kenneth Arrow, Samuel Karlin, and Paul Suppes. Stanford, CA: Stanford University Press, 1960.

[32] Wilson, Daniel J. "Is Embodied Technological Change the Result of Upstream R\&D? Industry-Level Evidence." 2002. Review of Economic Dynamics 5 (2) (April), pp. 342362.

[33] Young, Alwyn. "The Tyranny of Numbers: Confronting the Statistical Realities of the East Asian Growth Experience.” 1995. Quarterly Journal of Economics 110, pp. 641-680.

\section{Appendix: Derivation of Equation (2)}

Here for notational convenience we drop the country superscripts $i$. In each intermediate process $p$ the marginal product of labor is equal to the wage rate $w$, or

$$
(1-\alpha)\left(\sum_{j} x_{j}\right)^{\frac{1}{\gamma}-1} A_{p}^{\gamma} L_{p}^{(1-\alpha) \gamma-1} K_{p}^{\alpha \gamma}=w .
$$

Solving for $L_{p}$, summing over all sectors, and imposing the market-clearing condition $\sum_{p} L_{p}=$ $L$, we can solve for the wage $w$. Substituting back into the above equation we get

$$
\lambda_{p} \equiv \frac{L_{p}}{L}=\frac{A_{p}^{\frac{\gamma}{1-(1-\alpha) \gamma}} K_{p}^{\frac{\gamma}{1-(1-\alpha) \gamma}}}{\sum_{j} A_{j}^{\frac{\gamma}{1-(1-\alpha) \gamma}} K_{j}^{\frac{\gamma}{1-(1-\alpha) \gamma}}}=\frac{A_{p}^{\frac{\gamma}{1-(1-\alpha) \gamma}} \xi_{p}^{\frac{\gamma}{1-(1-\alpha) \gamma}}}{\sum_{j} A_{j}^{\frac{\gamma}{1-(1-\alpha) \gamma}} \xi_{j}^{\frac{\gamma}{1-(1-\alpha) \gamma}}} .
$$


We also have the condition that the marginal product of capital is equalized across sectors, or

$$
\alpha\left(\sum_{j} x_{j}\right)^{\frac{1}{\gamma}-1} A_{p}^{\gamma} L_{p}^{(1-\alpha) \gamma} K_{p}^{\alpha \gamma-1}=r .
$$

Dividing this by the pricing equation for labor we find the conventional result that the capital labor ratio is equalized across sectors:

$$
\frac{K_{p}}{L_{p}}=\frac{K}{L}
$$

which implies

$$
\xi_{p}=\lambda_{p}
$$

Hence we must solve the system of equations

$$
\xi_{p}=\frac{A_{p}^{\frac{\gamma}{1-(1-\alpha) \gamma}} \xi_{p}^{\frac{\gamma}{1-(1-\alpha) \gamma}}}{\sum_{j} A_{j}^{\frac{\gamma}{1-(1-\alpha) \gamma}} \xi_{j}^{\frac{\gamma}{1-(1-\alpha) \gamma}} .}
$$

Conjecturing that the solution takes the form $\xi_{p}=A_{p}^{a} /\left(\sum_{p} A_{p}^{a}\right)$ and substituting in the last equation one finds $a=\gamma /(1-\gamma)$, and hence the solution in the text. 
Table 1. Description of Capital Type Categories

\begin{tabular}{|c|c|c|}
\hline Capital-Type & ISIC code (Rev. 2) & Description \\
\hline Fabricated Metal Products & 381 & $\begin{array}{l}\text { Cutlery, hand tools, general hardware, metal furniture and fixtures, } \\
\text { structural metal products, etc.. }\end{array}$ \\
\hline Non-electrical equipment & $382-3825$ & $\begin{array}{l}\text { Engines \& turbines, agricultural machinery (including tractors, } \\
\text { excluding metal tools), metal \& wood-working machinery, industrial } \\
\text { trucks, military ordinance (including tanks), etc.. }\end{array}$ \\
\hline $\begin{array}{l}\text { Office, Computing, and } \\
\text { Accounting Machinery }\end{array}$ & 3825 & $\begin{array}{l}\text { Computers, calculators, typewriters, and other office equipment } \\
\text { (excluding photo-copiers) }\end{array}$ \\
\hline $\begin{array}{l}\text { Electrical Equipment (excluding } \\
\text { communications equipment) }\end{array}$ & 383-3832 & $\begin{array}{l}\text { Electrical industrial machinery, electrical appliances, and other } \\
\text { electrical apparatus }\end{array}$ \\
\hline Communications equipment & 3832 & $\begin{array}{l}\text { Semiconductors, wire \& wireless telephone equipment, radio \& TV } \\
\text { sets, audio recording equipment, signalling equipment, radar } \\
\text { equipment, etc.. }\end{array}$ \\
\hline Motor Vehicles & 3843 & $\begin{array}{l}\text { Automobiles and related parts (excludes industrial trucks and } \\
\text { tractors) }\end{array}$ \\
\hline Other Transportation Equipment & $3842+3844+3849$ & Railroad equipment, motorcycles \& bicycles, wagons \& carts, etc.. \\
\hline Aircraft & 3845 & Aircraft and related parts \\
\hline Professional Goods & 385 & $\begin{array}{l}\text { Measuring \& controlling equipment, photographic \& optical goods, } \\
\text { and watches \& clocks }\end{array}$ \\
\hline
\end{tabular}


Table 2. Statistics relating to Import Shares and R\&D

\begin{tabular}{|c|c|c|c|c|c|c|c|c|c|}
\hline Capital Type $\rightarrow$ & $\begin{array}{l}\text { Fabricated } \\
\text { Metal } \\
\text { Products } \\
\end{array}$ & $\begin{array}{l}\text { Non- } \\
\text { electrical } \\
\text { equipment }\end{array}$ & $\begin{array}{l}\text { Office, } \\
\text { Computing, } \\
\text { and } \\
\text { Accounting } \\
\text { Machinery } \\
\end{array}$ & $\begin{array}{l}\text { Electrical } \\
\text { Equipment }\end{array}$ & $\begin{array}{l}\text { Communi- } \\
\text { cations } \\
\text { equipment } \\
\end{array}$ & $\begin{array}{l}\text { Motor } \\
\text { Vehicles } \\
\end{array}$ & $\begin{array}{l}\text { Other } \\
\text { Transportation } \\
\text { Equipment } \\
\end{array}$ & Aircraft & $\begin{array}{l}\text { Professional } \\
\text { Goods }\end{array}$ \\
\hline \multicolumn{10}{|c|}{$\underline{1980}$} \\
\hline \multicolumn{10}{|c|}{ All Available $\overline{\text { Countries }(N=155)}$} \\
\hline Import Share Mean & 0.095 & 0.240 & 0.025 & 0.123 & 0.096 & 0.247 & 0.056 & 0.048 & 0.071 \\
\hline Std. Deviation & 0.043 & 0.096 & 0.023 & 0.049 & 0.053 & 0.091 & 0.065 & 0.068 & 0.036 \\
\hline $\min$ & 0.0043 & 0.0336 & 0.0004 & 0.0449 & 0.0246 & 0.0107 & 0.0019 & 0.0002 & 0.0048 \\
\hline $\max$ & 0.2421 & 0.6221 & 0.1108 & 0.3527 & 0.4290 & 0.5271 & 0.5168 & 0.5673 & 0.2304 \\
\hline corr. w/ income per capita & -0.1822 & -0.2053 & 0.2542 & 0.12 & 0.1331 & -0.0245 & -0.1371 & 0.009 & 0.2116 \\
\hline \multicolumn{10}{|c|}{ Non-R\&D Performing Sample Used in Our Regressions $(N=33)$} \\
\hline Import Share Mean & 0.082 & 0.264 & 0.022 & 0.124 & 0.103 & 0.230 & 0.045 & 0.057 & 0.071 \\
\hline Std. Deviation & 0.035 & 0.060 & 0.012 & 0.041 & 0.068 & 0.077 & 0.027 & 0.066 & 0.029 \\
\hline $\min$ & 0.034 & 0.078 & 0.007 & 0.049 & 0.044 & 0.055 & 0.017 & 0.002 & 0.044 \\
\hline $\max$ & 0.429 & 0.361 & 0.051 & 0.228 & 0.429 & 0.358 & 0.141 & 0.297 & 0.205 \\
\hline corr. w/ income per capita & -0.117 & -0.051 & 0.618 & 0.323 & 0.174 & 0.144 & -0.509 & -0.522 & 0.214 \\
\hline \multicolumn{10}{|c|}{$R \& D$ Measures } \\
\hline R\&D Stock (billions of US \$) & 112 & 484 & 519 & 688 & 1220 & 923 & 30 & 1370 & 321 \\
\hline ranking: & 8 & 6 & 5 & 4 & 2 & 3 & 9 & 1 & 7 \\
\hline R\&D flow intensity & 0.011 & 0.031 & 0.204 & 0.080 & 0.200 & 0.072 & 0.026 & 0.230 & 0.119 \\
\hline ranking: & 9 & 7 & 2 & 5 & 3 & 6 & 8 & 1 & 4 \\
\hline R\&D stock intensity & 0.060 & 0.164 & 1.113 & 0.515 & 1.044 & 0.400 & 0.143 & 1.426 & 0.561 \\
\hline ranking: & 9 & 7 & 2 & 5 & 3 & 6 & 8 & 1 & 4 \\
\hline \multicolumn{10}{|c|}{$\underline{1995}$} \\
\hline \multicolumn{10}{|c|}{ All Available Countries (165) } \\
\hline Import Share Mean & 0.083 & 0.209 & 0.060 & 0.144 & 0.114 & 0.238 & 0.034 & 0.047 & 0.071 \\
\hline Std. Deviation & 0.062 & 0.079 & 0.052 & 0.070 & 0.052 & 0.100 & 0.039 & 0.092 & 0.028 \\
\hline $\min$ & 0.0121 & 0.0273 & 0.0063 & 0.0116 & 0.0111 & 0.0102 & 0.0022 & 0.0000 & 0.0125 \\
\hline $\max$ & 0.5469 & 0.4790 & 0.4115 & 0.5851 & 0.3657 & 0.5545 & 0.3372 & 0.8842 & 0.2259 \\
\hline corr. w/ income per capita & -0.2479 & -0.1364 & 0.532 & 0.2713 & 0.2004 & -0.3207 & -0.4079 & 0.1386 & 0.3261 \\
\hline \multicolumn{10}{|c|}{ Non-R\&D Performing Sample Used in Our Regressions (40) } \\
\hline Import Share Mean & 0.057 & 0.242 & 0.062 & 0.157 & 0.125 & 0.218 & 0.023 & 0.041 & 0.074 \\
\hline Std. Deviation & 0.023 & 0.087 & 0.035 & 0.079 & 0.056 & 0.093 & 0.012 & 0.042 & 0.028 \\
\hline $\min$ & 0.023 & 0.052 & 0.013 & 0.085 & 0.068 & 0.042 & 0.007 & 0.001 & 0.037 \\
\hline $\max$ & 0.122 & 0.479 & 0.185 & 0.445 & 0.356 & 0.393 & 0.067 & 0.216 & 0.196 \\
\hline corr. w/ income per capita & -0.114 & -0.334 & 0.575 & 0.201 & 0.132 & -0.090 & -0.362 & 0.021 & 0.085 \\
\hline \multicolumn{10}{|c|}{$R \& D$ Measures } \\
\hline R\&D Stock (billions of US \$) & 202 & 887 & 1170 & 848 & 2280 & 1810 & 57 & 1880 & 801 \\
\hline ranking: & 8 & 5 & 4 & 6 & 1 & 3 & 9 & 2 & 7 \\
\hline R\&D flow intensity (\%) & 0.007 & 0.024 & 0.074 & 0.035 & 0.077 & 0.034 & 0.036 & 0.178 & 0.096 \\
\hline ranking: & 9 & 8 & 4 & 6 & 3 & 7 & 5 & 1 & 2 \\
\hline R\&D stock intensity (\%) & 0.043 & 0.130 & 0.521 & 0.211 & 0.448 & 0.185 & 0.212 & 1.304 & 0.455 \\
\hline ranking: & 9 & 8 & 2 & 6 & 4 & 7 & 5 & 1 & 3 \\
\hline
\end{tabular}


Table 3. Summary Statistics for Independent Variables

\begin{tabular}{|c|c|c|c|c|c|c|}
\hline $\begin{array}{c}\text { Variable } \\
\end{array}$ & \# of countries & $\begin{array}{l}1980 \\
\text { Mean }\end{array}$ & Std. Dev. & $\#$ of countries & $\begin{array}{r}1995 \\
\text { Mean }\end{array}$ & Std. Dev. \\
\hline $\begin{array}{l}\text { Inward FDI divided by total } \\
\text { investment (Inward FDI) }\end{array}$ & 32 & 0.34569 & 0.52048 & 38 & 0.57475 & 0.69683 \\
\hline $\begin{array}{l}\text { Outward FDI divided by total } \\
\text { investment (Outward FDI) }\end{array}$ & 32 & 0.00778 & 0.01754 & 38 & 0.06710 & 0.14134 \\
\hline $\begin{array}{l}\text { Industrial sector's share of } \\
\text { GDP (Industrial Share) }\end{array}$ & 32 & 0.352 & 0.094 & 38 & 0.324 & 0.077 \\
\hline $\begin{array}{l}\text { Service sector's share of } \\
\text { GDP (Services Share) }\end{array}$ & 32 & 0.484 & 0.088 & 38 & 0.550 & 0.088 \\
\hline $\begin{array}{l}\text { Government's share of GDP } \\
\text { (Gov't Share) }\end{array}$ & 32 & 0.130 & 0.045 & 38 & 0.123 & 0.040 \\
\hline $\begin{array}{l}\text { Intellectual Property Rights, } \\
\text { ranges from } 0 \text { to } 5 \text { (IPR) }\end{array}$ & 32 & 2.179 & 0.788 & 38 & 2.654 & 0.722 \\
\hline $\begin{array}{l}\text { Average years of education } \\
\text { for population } 25 \text { and over } \\
\text { (Human Capital) }\end{array}$ & 32 & 2.263 & 0.856 & 38 & 3.140 & 0.882 \\
\hline $\begin{array}{l}\text { Percentage of pop. with some } \\
\text { secondary education but no } \\
\text { tertiary education (Secondary } \\
\text { Ed.) }\end{array}$ & 32 & 16.466 & 9.973 & 38 & 25.108 & 12.313 \\
\hline $\begin{array}{l}\text { Percentage of pop. with less } \\
\text { than secondary education } \\
\text { (No Secondary Ed.) }\end{array}$ & 32 & 78.922 & 11.144 & 38 & 64.266 & 14.873 \\
\hline $\begin{array}{l}\text { Real GDP per capita (Income } \\
\text { per Capita) } \\
\text { Remoteness }\end{array}$ & $\begin{array}{l}32 \\
32\end{array}$ & $\begin{array}{l}5345.062 \\
9037.303\end{array}$ & $\begin{array}{l}3097.485 \\
1774.931\end{array}$ & $\begin{array}{l}38 \\
38\end{array}$ & $\begin{array}{l}6987.000 \\
9219.273\end{array}$ & $\begin{array}{l}5118.008 \\
2021550\end{array}$ \\
\hline $\begin{array}{l}\text { M3 as percent of GDP (Fin. } \\
\text { Development) }\end{array}$ & 32 & 40.930 & 18.083 & 38 & 51.152 & 25.562 \\
\hline $\begin{array}{l}\text { scale of } 0 \text { to } 10 \text { (Property } \\
\text { Rights) }\end{array}$ & 32 & 4.940 & 2.018 & $8 \mathrm{n} / \mathrm{a}$ & & ר/a \\
\hline
\end{tabular}


Table 4. Type-by-Type Relative Imports Regression

\begin{tabular}{|c|c|c|c|c|c|c|c|c|}
\hline & 2 & 3 & 4 & 5 & 6 & 7 & 8 & 9 \\
\hline Variable & $\begin{array}{c}\text { Non-elec } \\
\text { eqp }\end{array}$ & Computers & Elec Eqp & $\begin{array}{c}\text { Comm } \\
\text { Eqp }\end{array}$ & $\begin{array}{c}\text { Motor } \\
\text { Vehicles }\end{array}$ & $\begin{array}{c}\text { Other } \\
\text { Transport }\end{array}$ & Aircraft & Prof goods \\
\hline \multicolumn{9}{|c|}{ Panel A -- Dependent Variable $=$ Import Shares } \\
\hline TYPE DUMMY & 1.753 & $-10.105^{\star \star}$ & $-8.273^{* *}$ & $-7.576^{* *}$ & 2.285 & 0.322 & -3.957 & $-4.325 *$ \\
\hline Time Trend & -0.004 & 0.036 ** & $0.029 * *$ & $0.036 * *$ & -0.007 & 0.002 & 0.046 ** & 0.013 \\
\hline Inward FDI & $-0.131 * *$ & 0.049 & 0.076 ** & 0.098 ** & 0.019 & 0.071 ** & -0.043 & 0.022 \\
\hline Outward FDI & $0.030 * *$ & 0.002 & -0.016 & $-0.035 * *$ & -0.016 & $-0.029 * *$ & 0.029 & -0.024 \\
\hline Gov’t Share & -0.268 ** & -0.307 & -0.216 & 0.056 & 0.025 & 0.239 & 0.440 & -0.068 \\
\hline Industrial Share & 0.682 ** & -0.120 & -0.467 & -0.940 ** & -0.225 & -0.310 & -0.786 & -0.473 \\
\hline Services Share & -0.038 & 0.466 & -0.807 & 0.071 & 1.107 & $1.057^{* *}$ & -0.420 & 0.777 \\
\hline IPR & $-0.175 * *$ & 0.009 & 0.204 ** & 0.057 & 0.106 & 0.042 & -0.035 & 0.101 \\
\hline Human Capital & $0.179 *$ & 0.368 & 0.065 & 0.356 & -0.259 & 0.102 & 0.076 & 0.209 \\
\hline Income Per Capita & 0.057 & 0.496 ** & $0.356^{* *}$ & 0.215 & -0.393 & -0.035 & -0.218 & 0.131 \\
\hline
\end{tabular}

$\begin{array}{lr}\text { Pseudo R2 } & 0.302 \\ \mathrm{~N} & 1624\end{array}$

\# countries 40

Panel B -- Dependent Variable $=$ Import Shares

\begin{tabular}{|c|c|c|c|c|c|c|c|c|}
\hline TYPE DUMMY & -1.474 & $-21.510^{* *}$ & $-10.490^{* *}$ & $-14.257^{* *}$ & 3.825 & -6.259 * & -6.383 & -8.390 * \\
\hline Time Trend & -0.002 & $0.045^{* *}$ & 0.030 ** & $0.041 * *$ & -0.008 & 0.007 & 0.047 ** & 0.015 \\
\hline Inward FDI & $-0.131 * *$ & 0.015 & 0.067 * & $0.078^{* *}$ & 0.019 & $0.063^{* *}$ & -0.041 & 0.016 \\
\hline Outward FDI & 0.032 ** & 0.002 & -0.016 & $-0.033 * *$ & -0.017 & $-0.026 * *$ & 0.030 & -0.022 \\
\hline Gov't Share & $-0.209 *$ & -0.099 & -0.175 & 0.198 & -0.002 & 0.373 ** & 0.500 & 0.011 \\
\hline Industrial Share & $0.629 * *$ & -0.262 & -0.483 & $-0.982 * *$ & -0.192 & -0.370 & -0.844 & -0.523 \\
\hline Services Share & -0.103 & 0.154 & -0.858 & -0.016 & 1.150 & 0.995 ** & -0.530 & 0.696 \\
\hline IPR & $-0.155^{* *}$ & 0.036 & $0.213^{* *}$ & 0.069 & 0.096 & 0.066 & -0.035 & 0.114 \\
\hline Human Capital & 0.087 & 0.015 & -0.002 & 0.126 & -0.219 & -0.118 & 0.000 & 0.084 \\
\hline Income Per Capita & 0.071 & 0.659 ** & $0.382 * *$ & 0.288 & -0.406 & 0.003 & -0.183 & 0.173 \\
\hline Remoteness & 0.332 * & $1.068^{* *}$ & 0.216 & 0.669 * & -0.150 & $0.691^{* *}$ & 0.229 & 0.407 \\
\hline Pseudo R2 & 0.311 & & & & & & & \\
\hline $\mathrm{N}$ & 1624 & & & & & & & \\
\hline \# countries & 40 & & & & & & & \\
\hline
\end{tabular}

Panel C -- Dependent Variable $=$ Import Shares

\begin{tabular}{|c|c|c|c|c|c|c|c|c|}
\hline TYPE DUMMY & -0.332 & $-23.242^{* *}$ & $-12.975^{* *}$ & $-15.618^{* *}$ & 1.402 & $-7.217^{*}$ & -9.160 & -9.117 * \\
\hline Time Trend & 0.000 & 0.044 ** & 0.019 ** & $0.036^{* *}$ & -0.011 & 0.010 & 0.039 ** & 0.012 \\
\hline Inward FDI & $-0.130 * *$ & 0.015 & 0.057 & 0.073 * & 0.019 & 0.067 ** & -0.050 & 0.015 \\
\hline Outward FDI & 0.033 ** & 0.000 & -0.027 * & $-0.038 * *$ & -0.019 & $-0.024 *$ & 0.024 & -0.025 \\
\hline Gov't Share & -0.169 & -0.130 & $-0.403^{* *}$ & 0.078 & -0.071 & $0.415^{* *}$ & 0.348 & -0.045 \\
\hline Industrial Share & $0.647 * *$ & -0.268 & $-0.559 *$ & -1.046 ** & -0.185 & -0.280 & -1.032 * & -0.571 \\
\hline Services Share & -0.106 & 0.105 & -0.717 & 0.010 & 1.159 & 1.024 ** & -0.518 & 0.688 \\
\hline IPR & $-0.133 * *$ & 0.034 & 0.140 & 0.027 & 0.072 & 0.105 & -0.092 & 0.094 \\
\hline Human Capital & 0.083 & -0.004 & 0.129 & 0.192 & -0.227 & -0.195 & 0.047 & 0.118 \\
\hline Income Per Capita & 0.088 & 0.646 ** & 0.266 & 0.248 & -0.466 & -0.044 & -0.163 & 0.166 \\
\hline Remoteness & 0.236 & $1.234^{* *}$ & 0.380 & 0.735 * & 0.100 & 0.903 ** & 0.338 & 0.428 \\
\hline Fin. Development & -0.131 & 0.079 & $0.633^{* *}$ & 0.335 ** & 0.215 & -0.162 & 0.491 ** & 0.175 \\
\hline
\end{tabular}

Pseudo R2 0.318

$\mathrm{N} \quad 1584$

\# countries 39 
Table 4 (continued). Type-by-Type Relative Imports Regression

\begin{tabular}{|c|c|c|c|c|c|c|c|c|}
\hline & 2 & 3 & 4 & 5 & 6 & 7 & 8 & 9 \\
\hline Variable $^{a}$ & $\begin{array}{c}\text { Non-elec } \\
\text { eqp }\end{array}$ & Computers & Elec Eqp & $\begin{array}{c}\text { Comm } \\
\text { Eqp }\end{array}$ & $\begin{array}{c}\text { Motor } \\
\text { Vehicles }\end{array}$ & $\begin{array}{c}\text { Other } \\
\text { Transport }\end{array}$ & Aircraft & Prof goods \\
\hline \multicolumn{9}{|c|}{ Panel D -- Dependent Variable $=$ Import Shares } \\
\hline TYPE DUMMY & 0.895 & $-21.848^{\star \star}$ & $-11.374^{\star \star}$ & $-14.610^{* *}$ & 2.090 & -5.505 & -5.781 & $-11.503^{*}$ \\
\hline Time Trend & -0.002 & $0.045^{* *}$ & 0.023 * & $0.037^{* *}$ & -0.018 & -0.001 & $0.077^{* *}$ & 0.021 \\
\hline Inward FDI & -0.112 ** & 0.008 & 0.066 & $0.080 *$ & -0.003 & 0.052 & -0.001 & 0.037 \\
\hline Outward FDI & 0.021 * & 0.019 & -0.024 & -0.031 & -0.012 & -0.012 & 0.025 & -0.021 \\
\hline Gov't Share & -0.259 * & -0.091 & -0.177 & 0.192 & -0.139 & 0.299 & 0.383 & 0.134 \\
\hline Industrial Share & $0.680 * *$ & 0.097 & -0.454 & -1.032 ** & -0.164 & -0.353 & -0.818 & -0.689 \\
\hline Services Share & 0.152 & 0.775 & -0.540 & 0.413 & 0.814 & 0.725 & -0.484 & 0.572 \\
\hline IPR & -0.091 & 0.001 & 0.158 & 0.058 & -0.006 & 0.017 & 0.069 & 0.169 \\
\hline Human Capital & -0.079 & 0.016 & 0.066 & 0.117 & -0.070 & 0.059 & -0.158 & -0.067 \\
\hline Income Per Capita & 0.076 & 0.472 & 0.139 & 0.194 & -0.375 & -0.013 & -0.535 & 0.169 \\
\hline Remoteness & 0.159 & 1.375 * & 0.439 & 0.798 & -0.055 & 0.636 & 0.056 & 0.711 \\
\hline Fin. Development & $-0.217^{*}$ & 0.051 & 0.431 * & 0.153 & 0.353 & 0.085 & 0.239 & -0.021 \\
\hline Property Rights & 0.030 & -0.003 & 0.031 & 0.028 & -0.060 & -0.033 & 0.130 ** & 0.046 \\
\hline
\end{tabular}

$\begin{array}{lr}\text { Pseudo R2 } & 0.307 \\ \mathrm{~N} & 1120\end{array}$

\# countries 38

Panel E -- Dependent Variable = Import Shares; Alternative Human Capital Measure

\begin{tabular}{|c|c|c|c|c|c|c|c|c|}
\hline TYPE DUMMY & 3.2613 & -23.5506 ** & $-13.31^{\star *}$ & $-17.85 * *$ & -1.201 & -6.20497 & 2.4321 & $-14.2483^{* *}$ \\
\hline Time Trend & -0.006 & 0.048288 ** & 0.0261 ** & $0.0424 * *$ & -0.013 & 0.001037 & 0.0659 ** & 0.02374 \\
\hline Inward FDI & $-0.115 * *$ & 0.012405 & 0.0667 & 0.0823 * & $-2 E-04$ & 0.053857 & -0.014 & 0.04033 \\
\hline Outward FDI & 0.0208 ** & 0.01893 & -0.024 & -0.031 & -0.01 & -0.01362 & 0.0195 & -0.0184 \\
\hline Gov't Share & -0.263 * & -0.10404 & -0.172 & 0.2099 & -0.157 & 0.290964 & 0.322 & 0.13755 \\
\hline Industrial Share & 0.6998 ** & 0.095657 & -0.471 & $-1.07 * *$ & -0.146 & -0.33926 & -0.578 & -0.7395 \\
\hline Services Share & 0.1564 & 0.785861 & -0.551 & 0.4077 & 0.8844 & 0.727002 & -0.508 & 0.58333 \\
\hline IPR & -0.096 & 0.021767 & 0.144 & 0.0575 & -0.045 & 0.034115 & 0.0583 & 0.15582 \\
\hline Secondary Ed. & -0.012 & 0.007408 & 0.0128 & 0.0165 & 0.0412 & 0.000717 & -0.033 & 0.01927 \\
\hline No Secondary Ed. & -0.01 & 0.008912 & 0.0083 & 0.012 & 0.0333 & 0.001421 & -0.028 & 0.01714 \\
\hline Income Per Capita & 0.0557 & 0.490251 & 0.151 & 0.2173 & -0.382 & 0.000819 & -0.606 * & 0.1656 \\
\hline Remoteness & 0.0417 & 1.425865 ** & 0.5346 & 0.9781 ** & -0.076 & 0.678978 * & -0.387 & 0.79785 \\
\hline Fin. Development & -0.202 & 0.04036 & 0.4298 ** & 0.1327 & 0.3471 & 0.069998 & 0.2107 & -0.01643 \\
\hline Property Rights & 0.0297 & -0.00264 & 0.027 & 0.0281 & -0.075 & -0.03151 & 0.1234 * & 0.04142 \\
\hline Pseudo R2 & 0.3087 & & & & & & & \\
\hline $\mathrm{N}$ & 1120 & & & & & & & \\
\hline \# countries & 38 & & & & & & & \\
\hline
\end{tabular}

Note: For each of the country-specific factors above, the log of the factor is what is actually included in the regression. 
Table 5. Embodied R\&D Regressions

\begin{tabular}{|c|c|c|c|c|c|}
\hline & 1 & 2 & 3 & 4 & 5 \\
\hline $\begin{array}{l}\text { Dependent } \\
\text { Variable } \rightarrow\end{array}$ & \multirow[b]{2}{*}{ Import Share } & \multirow[b]{2}{*}{ Import Share } & \multirow[b]{2}{*}{ Import Share } & \multirow[b]{2}{*}{ Import Share } & \multirow[b]{2}{*}{ Import Share } \\
\hline $\begin{array}{l}\text { Independent } \\
\text { Variable } \downarrow\end{array}$ & & & & & \\
\hline $\mathrm{LOG}\left(\mathrm{R}_{\mathrm{P}} / \mathrm{R}_{1}\right)$ & -1.252859 ** & -4.552452 ** & $-4.629257^{\star *}$ & -3.11556 ** & -0.659959 ** \\
\hline Time Trend & $0.007955^{* *}$ & 0.010053 ** & 0.009396 ** & 0.010026 ** & 0.002944 \\
\hline Inward FDI & -0.032364 ** & $-0.03583^{* *}$ & -0.036363 ** & -0.027925 ** & $-0.031767 * *$ \\
\hline Outward FDI & 0.003677 & $0.00472 *$ & 0.004211 & 0.002052 & 0.000821 \\
\hline Industrial Share & 0.089115 & 0.039876 & 0.037718 & 0.111496 & 0.22264 ** \\
\hline Services Share & 0.01481 & -0.073098 & -0.062474 & 0.21392 * & $0.282471^{* *}$ \\
\hline Gov’t Share & $-0.092724^{* *}$ & -0.026741 & -0.042333 & -0.035505 & -0.040233 \\
\hline IPR & $-0.035095^{* *}$ & -0.024685 & -0.024175 & -0.00626 & -0.011923 \\
\hline Human Capital & $0.14201^{\star *}$ & 0.042089 & 0.055658 & -0.021555 & \\
\hline $\begin{array}{l}\text { No Secondary Ed. } \\
\text { Secondary Ed. }\end{array}$ & & & & & $\begin{array}{l}-0.005711^{* *} \\
-0.006401^{* *}\end{array}$ \\
\hline Income per Capita & $0.064767^{* *}$ & 0.102094 ** & $0.091809 * *$ & 0.014827 & -0.001227 \\
\hline Remoteness & & 0.324814 ** & $0.328901 * *$ & 0.281282 ** & 0.195624 ** \\
\hline Fin. Development & & & 0.034622 & -0.037535 & -0.063883 * \\
\hline Property Rights & & & & $0.029374^{* *}$ & $0.033105^{* *}$ \\
\hline N & 1160 & 1160 & 1120 & 808 & 808 \\
\hline \# Countries & 40 & 40 & 39 & 38 & 38 \\
\hline
\end{tabular}

Note: For each of the country-specific factors above, it is the log of the factor interacted with $\log \left(R_{p} / R_{1}\right)$ that is included in the regression. 
Table 6. Relationship between Capital Quality Measures and Income p.c. (1990 sample)

Ratio of 90-10

Interpercentile

\begin{tabular}{|c|c|c|c|c|}
\hline Quality Measure & Gamma & Ratio of Log-Variances & Ranges & Correlation \\
\hline \multirow{3}{*}{$\begin{array}{l}\text { Q predicted by Type-By-Type } \\
\text { Regression (from Table 4, panel D) }\end{array}$} & 0.25 & 4.029 & 3.367 & 0.289 \\
\hline & 0.5 & 0.457 & 0.478 & 0.277 \\
\hline & 0.75 & 0.052 & 0.251 & 0.263 \\
\hline \multirow{3}{*}{$\begin{array}{l}\text { Q' predicted by Type-By-Type } \\
\text { Regression (from Table 4, panel D) }\end{array}$} & 0.25 & 3.963 & 3.539 & 0.298 \\
\hline & 0.5 & 0.440 & 0.481 & 0.298 \\
\hline & 0.75 & 0.049 & 0.247 & 0.298 \\
\hline \multirow{3}{*}{$\begin{array}{l}\text { Q predicted by Embodied R\&D } \\
\text { Regression (Table } 5 \text {, row D) }\end{array}$} & 0.25 & 2.943 & 2.952 & 0.385 \\
\hline & 0.5 & 0.347 & 0.461 & 0.414 \\
\hline & 0.75 & 0.041 & 0.244 & 0.437 \\
\hline \multirow{3}{*}{$\begin{array}{l}\text { Q' predicted by Embodied R\&D } \\
\text { Regression (Table 5, row D) }\end{array}$} & 0.25 & 2.775 & 2.564 & 0.349 \\
\hline & 0.5 & 0.308 & 0.432 & 0.349 \\
\hline & 0.75 & 0.034 & 0.239 & 0.349 \\
\hline
\end{tabular}

Note: Numerator in ratios corresponds to quality measure; denominator corresponds to income per capita. 
Figure 1. Correlations between Import Shares and Investment Shares, by Country

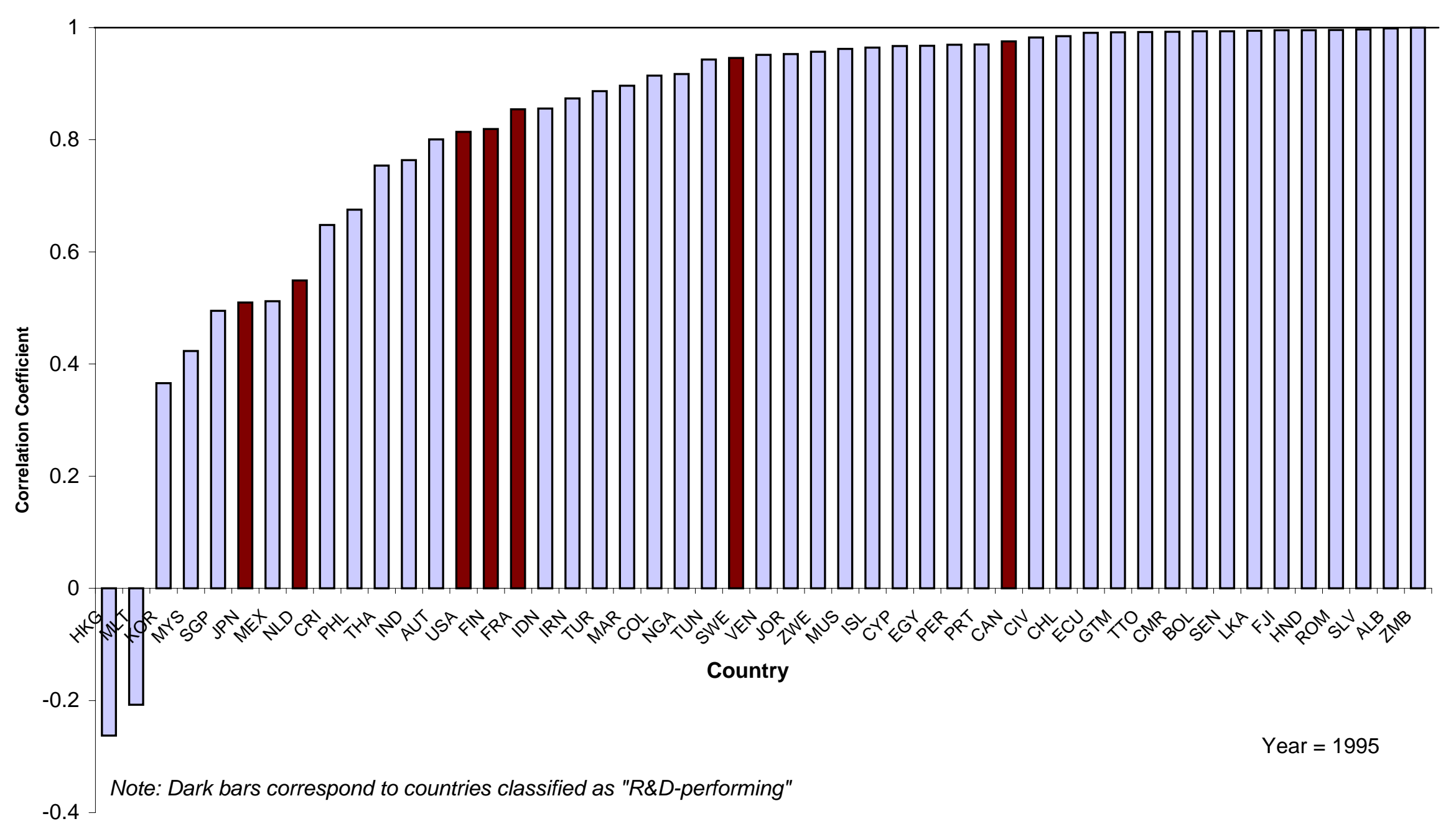


Figure 2. Scatterplots of Quality Measure and Income per Capita (1990 sample)
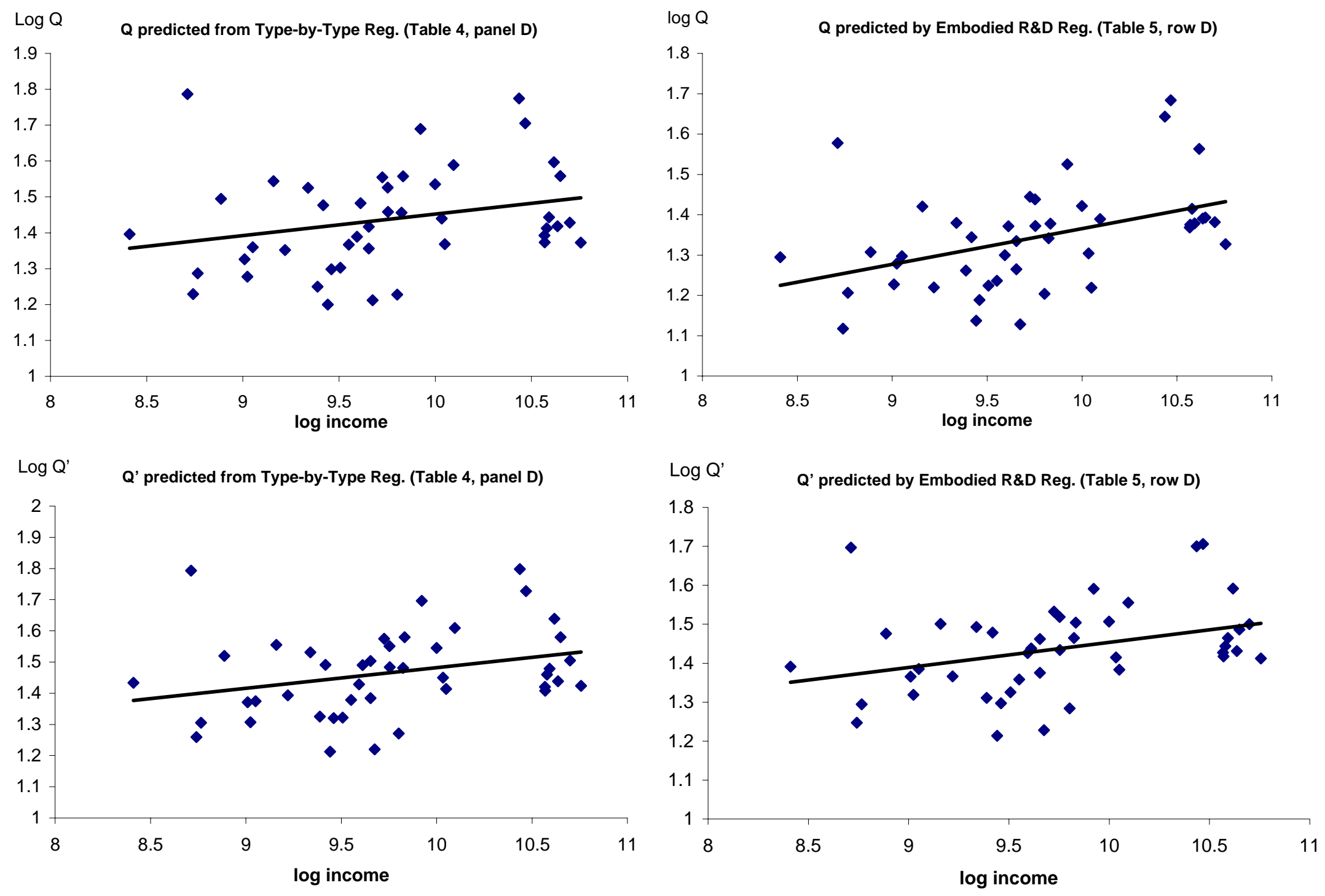

Note: $Q$ and $Q$ ' measures above are constructed assuming $\gamma=0.75$. 